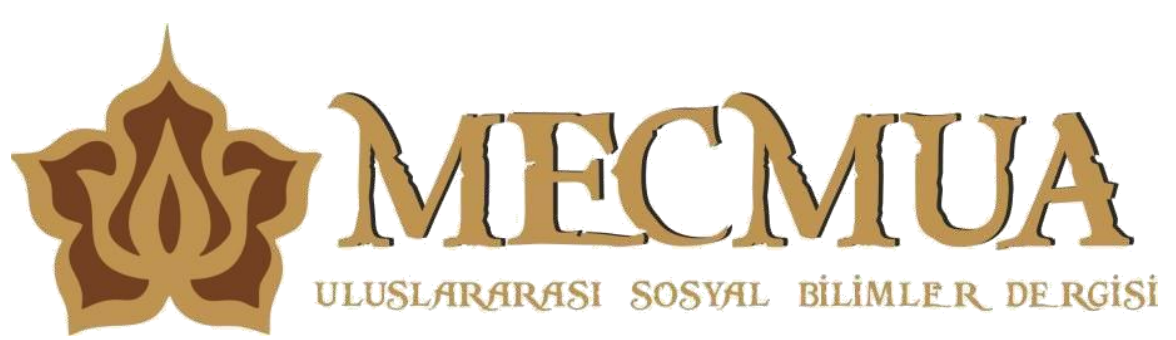

Güz 2019, Yıl: 4, Sayı: 8, ss. 48-84

Doi Number: 10.32579/mecmua.595831

Araştırma Makalesi / Research Article

$\underline{\text { Yayın Süreci / Publication Process }}$

Yükleme Tarihi: 23.07.2019 / Kabul Tarihi: 17.09.2019

Salhadin GÖK *

Özlem KILINÇÇEKER **

\title{
TÜRK KADININ SIYYASETE GIRISS SÜRECİ VE İLK KADIN SAYLAV MİHRİ İFFET PEKTAŞ
}

\begin{abstract}
ÖZ
Tarih boyunca kadın hakları hem dünyada hem de Türkiye'de en tarış̧malı konulardan biri olmuştur. Osmanlı Devleti'nde, Tanzimat ve Meşrutiyetle örgütlenen kadınlara ilk siyasi haklar Cumhuriyet döneminde verilmiştir. Ancak Türk kadını, siyasi haklarını büyük bir mücadele ile kazanmıştır. İlk olarak bu hakları 1930 yılında belediye seçimleri, 1933 yılında ise köy muhtarlığı seçimlerine katılma hakkı olarak elde etmiş̧ir. Milletvekili Seçme ve Seçilme hakkını ise 5 Aralık 1934 yılında Anayasa 'da yapılan değişiklikle kazanmıştır. Böylece Türk kadını birçok Avrupa ülkesindeki kadınlardan önce seçme ve seçilme hakkını elde etmiştir. 8 Şubat 1935'te yapılan ilk seçimde 18 kadın milletvekili parlamentoya girmiştir. Bu kadın milletvekillerinden birisi de Malatya Milletvekili Mihri İffet Pektaş'tır. Bu çalışmada da Türkiye'nin çağdaş modern öncü kadın figürlerinden biri olmayı başarmış İngilizce ve Fransızca öğretmeni Mihri Pektaş'ın Malatya basınında çıkan haberleri, hayatı ve Meclisteki faaliyetleri ele alınmıştır.
\end{abstract}

Anahtar Kelimeler: Atatürk, Mihri İffet Pektaş, Malatya, Kadın Hakları, Robert Koleji.

* iD Dr. Öğr. Üyesi, Adıyaman Üniversitesi Fen Edebiyat Fakültesi Tarih Bölümü, sgok@adiyaman.edu.tr

** (D) Öğr. Gör., Adiyaman Üniversitesi Fen Edebiyat Fakültesi Tarih Bölümü, okilincceker@adiyaman.edu.tr 


\begin{abstract}
Throughout history, women's rights have been one of the most controversial issues both in the world and in Turkey. Although women were organized in the Ottoman Empire during the Tanzimat and the Constitutional Monarchy periods, they gained their first political rights during the Republican period. Turkish women have obtained their political rights through a great struggle. Firstly, they attained the right to participate in the municipality elections in 1930, and then the right to participate in the Muhtar elections in 1933. Furthermore, they acquired the right to vote and to be elected through the amendment made in the Constitution on December 5, 1934. Thus, Turkish women have obtained the right to vote and to be elected earlier than the women in many European countries. Eighteen women were elected to the parliament in the first election held on February 8, 1935. One of these women deputies was the Malatya deputy Mihri Iffet Pektaş, a teacher of English and French who achieved to become one of the modern contemporary pioneer women of Turkey. This paper investigates the news about Mihri Pektaş in the local press of Malatya, her life and her political activities in the Parliament.
\end{abstract}

Key Words: Atatürk, Mihri İffet Pektaş, Malatya, Women's Rights, Robert College.

\title{
Giriş
}

Tarih boyunca insanlık, kadının toplumsal hayattaki yerini ve önemini tartışmıştır. Bu konuyu farklı görüşler çerçevesinde ele alarak, kadının toplumda nerede, nasıl, kiminle, hangi konumda duracağını tartışarak günümüze kadar getirmiştir. Birçok din yorumcusu kadını "acıların kaynağı", "günahın sembolü", "şeytanın aracı" olarak tanımlanmıştır. Öyle ki; nüfus sayımlarında bile hayvanları istatistiksel verilere dâhil edilirken kadınlar bunun dışında bırakılmıştır. Oysa kadın; avcıtoplayıcı insan topluluklarından bu yana toplumun temel taşı, aydınlanma çağının en önemli parçası olmuştur. Ancak kadınların ve erkeklerin aynı haklara sahip olmadığı toplumlarda, eşitlik sorunu hep var olmaya devam etmiştir. Bu sorun, 20. Yüzyıl'dan itibaren tüm dünyada kadın ile erkekler arasında eşit siyasi ve sosyal haklar elde etme tartışmalarını beraberinde getirmiştir. Bu bağlamda ilk zamanlarda kadınlara kanunlarla birçok hak verilmiş olsa da, kadınların bu haklarından toplum baskıs1, gelenekler ve dini sebeplerle yeterince faydalanamadıkları görülmüştür(Duroğlu, 2007: 9; Feyzioğlu, 1992: 881).

İslamiyet öncesi dönemde Türk kadını, tarım ve hayvancılıkla uğraşan, ticaret yapan, savaşta ve kurulan mecliste erkeğin yanında yer alan konumda iken İslamiyet'le birlikte kadının sosyal hayat içindeki statüsü değişmiştir. Müslümanlığın kabulünden sonra İran ve Arap kültürlerinden etkilenen, İslam dininin temelinde olmamasına rağmen yanlış ya da eksik yorumlamalardan kaynaklanan, geleneklerle karıştırılan kadın haklarının, dini bir baskı ile karşı karşıya kaldığı görülmektedir. Buna bir de Osmanlı Devleti'nin kuruluşundan sonra toplum ve siyasi hayatta kendini gösteren Bizans etkisi de eklenince kadının sosyal yaşam alanı iyice daralmıştır(Oruç, 2010: 7; Feyzioğlu, 1992: 881). Türk kadınının konumu ve statüsü tarihi süreç içinde farklı şekillerde tanımlanmış dönemsel, bölgesel ve kültürel olarak da farklı kimlikler kazanmıştır. Klasik dönem Osmanlı kadını ile Tanzimat dönemi kadını ya da Osmanlı ve Cumhuriyet dönemi kadınları arasında belirgin bir 
ayrım vardır. Yine aynı ayrımı İstanbul kadını ile Anadolu kadını arasında da görmek mümkündür( Oruç, 2010: 7). Öyle ki Geleneksel ve dini öğretiler erkekleri toplumsal yaşamda aktif kılarken, kadınları ev içinde sınırlı bırakmıştır. Ancak Meşrutiyet dönemi ve arkasından gelen savaş yılları çalışma hayatında erkeklerin yerine kadınların geçmesinin ortamını sağlamıștır. Özellikle 1912'de çıkan Balkan Savaşları ile erkek nüfusunda yaşanan azalma, kadınları sosyoekonomik yaşamın içine girmeye zorlamıştır. Bu zorunlu giriş burjuva kadınlarını, sosyal hizmet anlayışının en önemli unsuru olan derneklere yöneltmiştir. Balkan Savaşı ile yurtta oluşan "Balkan faciası" ortamında, protesto mitingleri yapmak, yaralılara bakmak, Balkanlardan göç eden dul ve yetimlere yardım etmek kadınlara kalmıştır. (Duroğlu, 2007: 22; Şimşek, 2017: 353) Bu çetin mücadeleler, donanıml1-aydın İstanbul kadınını öne çıkarırken, daha sonraki dönemde özellikle Milli Mücadelede gösterdikleri başarılar nedeniyle, Anadolu kadınını ön plana çıkarmıştır (Oruç, 2010: 7; İlkhan, 2018; 74).

\section{1-Siyasi Hakların Elde Edilmesinde Kadın Hareketleri}

1919-1923 arasındaki askeri ve siyasi başarılar, 29 Ekim 1923'te Cumhuriyetin ilanını getirmiştir. Türk kadını bu süre zarfında aktif olarak rol almıştır, işgallere karşı protesto mitingleri düzenlemiş, hatta yabancı ülkelere yazılar göndererek işgallere karşı çıkmada üstüne düşen görevi layığıyla yapmıştır (Afetinan, 1992: 915). Bununla da yetinmeyen Türk kadını, Kurtuluş Savaşı yıllarında Anadolu'da ilk büyük sosyal ve siyasi kadın teşkilatı olan Anadolu Kadınları Müdafaa-i Vatan Cemiyetini kurmuştur. Daha sonra kadınlar, siyasal anlamda ilk mücadelesini Ulusal Bağımsızlık Savaşı kazanıldıktan sonra kadın hareketi olarak tarihe geçen Nezihe Muhittin ve arkadaşlarının kurduğu Kadınlar Halk Fırkasıyla vermiştir (Oruç, 2010: 33; İşat, 2006: 15; Uzun, 2017:75; Bulut ve Vurmay, 2017: 8). Ancak Kadınlar Halk Fırkası'nın kuruluş arifesinde TBMM üyelerinin kadınlara siyasal hakların verilmesine hazır olmadığ (hem I. Grup hem de II. Grup üyelerinin) konusunda görüş birliği içerisinde olmasına rağmen, basın hep gündeminde tutarak kamuoyunun nabzını ölçmeye devam etmiştir. Bu kapsamda dönemin gazeteleri de kadınların seçimlerle ilgili görüşlerini almak için anketler düzenlemiştir (Afetinan, 1992: 915; Oruç, 2010: 34; Yılmaz, 2011:143; Çanak, 2016: 30.).

Kadın haklarına karşı hoşgörüsüzlüğün hâkim olduğu bu yıllarda boş durmayan Türk kadını 7 Şubat 1924 tarihinde "Türk Kadınlar Birliği”" adı altında tek parti

\footnotetext{
${ }^{1}$ Türk Kadınlar Birliği kurulduğu 7 Şubat 1924 tarihinde kendini feshettiği 10 Mayıs 1935 tarihine kadar tek parti yönetiminin önemli tek kadın derneğidir. Özellikle Nezihe Muhittin'in başkanlığı döneminde TKB kadınların siyasi haklarını elde etme konusunda radikal bir çizgiyi benimsemiştir. Dernek, kadınların siyasal, toplumsal ve ekonomik alanlarda kabul görüp özgürleşmelerini, kurucu unsur olarak devlet otoritesinde söz sahibi olmaları için çalışmıştır. Ancak kurulduğu yıllarda derneğin "kadının mefkûresi" adı ile verdikleri mücadeleleri o dönem için şartların uygun olmadığı gerekçesiyle aşırı talepler olarak görülmüştür. Öyle ki derneğin başarısını tehlikeli bulan çevreler TKB yönetimini ağır iftiralarla yıpratmıştır. Sonunda da Nezihe Muhittin usulsüzlük iddialarıyla yönetimden uzaklaştırılmışıtır. Yerine geçen Latife Bekir'in döneminde ise sadece siyasi hak taleplerini geri planda tutan bir hayır kurumu olarak çalışmalarına devam etmiştir. Dernek bu yıllarda faaliyetlerini devletin siyasetiyle uyumlu, tek parti yönetimin belirlediği sınırlar içinde sürdürmüştür. Çalışmaları iktidarın bünyesinde sınırlı olmasına rağmen kadınların siyasi haklarını elde ettiği güne kadar mücadele veren tek dernektir (Oruç, 2010: 119).
} 
yönetiminde önemli radikal bir çizgiyi benimsemiş olan ilk derneklerini kurmuşlardır. Bu dernek kadınların siyasal, toplumsal ve ekonomik alanlarda kabul görüp özgürleşmesi, karar mekanizmalarında söz sahibi olmaları ve yeni yönetimde kurucu unsur olarak yer almaları gibi konularda önemli çalışmalar yapmıştır. O günlerde Türk kadınlarının bu faaliyetleri zor ve sancılı olsa da yapılan bu çalışmalar ileride Cumhuriyet döneminde kendilerine verilecek hakların yolunu açması açısından fayda sağlamıştır (Oruç, 2010: 119; Uzun,2017: 75).

Türkiye'de Mustafa Kemal Paşa'nın tam desteğini alan kadınlar için kadın hakları ile ilgili ilk ciddi kırılma Cumhuriyetin ilanı ile başlamıştır. Bu yıldan itibaren Mustafa Kemal Paşa'nın desteği ile Türk kadınının toplumsal statüsünü geliştirmek için çeşitli adımlar atılmıştır. 1924 yılında kabul edilen Tevhid-i Tedrisat Kanunu (Öğretim Birliği Yasası) ile kadın ve erkeklerin eşit öğretim imkânlarından yararlanması sağlanmış, kadınların eğitimine ve eşitliğine büyük önem verilmiştir. Böylece yeni eğitim sistemi, laik bir niteliğe sahip olarak gelişip yaygınlaşırken, çağdaş uygulamalar da gerçekleştirilmiştir. Özellikle 1925-1926 yılları kadın haklarının sık sık tartışıldığı yıllar olmuştur.

1927 y1lına kadar bu durumda devam eden kadınların mücadelesi, 21 Haziran 1927 tarihinde TBMM'i Türk Kadınlar Birliği'nin kadınlar için siyasal hak talebini tartışmaya başlaması ile yeni bir ivme kazanmıştır (Oruç, 68). Açıldığı günden itibaren yoksul çocuk ve kadınlara yardım çalışmaları, çeşitli toplantılar ve siyasal haklar arayan TKB'nin Türk kadınının siyasallaşma sürecinde, 1930 yerel seçimlerinde, 1934 belediye seçimlerinde emeğinin karşılığını aldığı görülür (Oruç, 2010: 103; Demir ve Yüksel, 2017: 235). Böylece Cumhuriyet döneminde yapılan ilk seçimlerle kadınının bir birey ve demokratik bir toplumunun olmazsa olmazı olduğunu savunarak kadının toplumdaki haklarını elde etmesinde büyük çalışmalara imza atmıştır. (Oruç, 2010: 103) TKB, 1935 y1lında V. dönem milletvekili seçimlerinden sonra kadın milletvekillerinin Meclise girmesiyle aynı yıl amaçlarını gerçekleştirdikleri düşüncesi ile dernek çalışmalarına ara vermiş̧ir (Yetkin, 1983: 84-86; İşat, 2006: 67).

İlk kez 3 Nisan 1930'da Belediye Seçimlerinde seçme-seçilme hakkını kullanan Türk kadını, siyasi manada ikinci hakkını ise Köy Muhtarlı̆̆ ve İhtiyar Heyetine katılmakla elde etmiştir. Bu hak 1924"te "Köy Yasası"nın 20, 25 ve 30. Maddelerinin değiştirilmesi, 26 Ekim 1933'te ise 1924 tarihli 442 Sayılı Köy Kanunu'nun değiştirilmesi ile sağlanmıştır (Gökçimen, 2008: 20; Yıldız, 2012:66).

Kadınlar 5 Aralık 1934 tarihinde Başbakan İsmet İnönü ve 191 arkadaşının verdiğgi; 1924 Teşkilât-1 Esasiye Kanunu'nun 10. ve 11. Maddelerinin değiştirilmesine ilişkin kanun teklifi ile milletvekili seçme ve seçilme hakkını kazanmıştır. Yeni kanun ile kadın ve erkek her Türk vatandaşının seçme yaşı 22, seçilme yaşı 30 olarak belirlenmiştir. Böylece, kadın ile erkek arasındaki eşitsizlik ortadan kalkmış siyasal haklar bakımından kadın ile erkek aynı konuma gelmiştir. Bu adımın Türkiye'nin daha demokratik bir ortama kavuşması ve siyasal katılımın boyutlarının genişletilmesi amacıyla atıldığını söylemek mümkündür. Zira 1930 yılı Gazi 
Mustafa Kemal Paşa'nın da isteği doğrultusunda kurulan Serbest Cumhuriyet Fırkası ile çok partili hayata geçiş denemesinin yaşandığı bir dönemdir ( Yıldız, 2012:126).

Siyasal ve sosyo-ekonomik alanlarda yapılan inkılaplarla kadınlar, ülke yönetiminde söz sahibi olmuştur. Kadınlarla ilgili kanuni düzenlemeler Mustafa Kemal Paşa'nın isteği ve İsmet İnönü hükümetinin teklifi ile TBMM'de müzakere edildiği zaman, fikirlerini açıklayan milletvekillerinin de olumlu beyanlarda bulundukları gözlenmiştir. Mustafa Kemal Paşa, bu konu için gerek hükümet üyeleri, gerekse çevresinde bulunanlarla görüşmeler yaparken, herkesin fikrine önem vermekle beraber, yapılacak olan inkılâplara, lehte ve aleyhte olanlar arasında müzakere ettiği de görülmüsstür. Dolayısıyla TBMM'de yapılan görüşmeler neticesinde Türk kadınına seçme ve seçilme hakkının verilmesi kadınının siyasi alanda kazandığı en son kazanım olmuştur (Gökçimen, 2008: 21; Yıldız, 2012: 68-72; Doğramacı, 1992: 910; Afetinan, 1992: 917).Kazanılan bu hakların pratiğe dökülmesi ise ilk kez TBMM'nin beşinci dönem seçimlerinde gerçekleşmiştir. İlk kadın milletvekilleri 1 Mart 1935 tarihinde Meclis'e girdiler (Oruç, 2010: 103; Gökçimen, 2008: 22). Meclise girmeyi başaran 18 milletvekilinin mesleklerine bakıldığında 13'ünün öğretmen olduğu görülmektedir². (Hamzaoğlu, 2017: 87; Bulut ve Vurmay, 2017; 9).

\begin{tabular}{|l|l|l|l|}
\hline Adı-Soyadı & Seçildiği İl & Adı-Soyadı & $\begin{array}{l}\text { Seçildiği } \\
\text { İl }\end{array}$ \\
\hline $\begin{array}{l}\text { Emine (Mersin } \\
\text { Gönenç } \\
\text { Belediye Meclis Üyesi) }\end{array}$ & Afyonkarahisar & Hatice Özgener Öğretmen & Çankırı \\
\hline $\begin{array}{l}\text { Hatı (Satı) Çırpan } \\
\text { (Tıpan) (Kazan Köyü } \\
\text { Muhtarı) }\end{array}$ & Ankara & $\begin{array}{l}\text { NakiyeElgün } \\
\text { Umumi Meclis Üyesi ve } \\
\text { Öğretmen) }\end{array}$ & Erzurum \\
\hline $\begin{array}{l}\text { Şükran Örs Baştuğ } \\
\text { (Öğretmen) }\end{array}$ & Antalya & Fakihe Öymen (Öğretmen) & İstanbul \\
\hline $\begin{array}{l}\text { Sabiha Gökçül Erbay } \\
\text { (Öğretmen) }\end{array}$ & Balıkesir & $\begin{array}{l}\text { Benal Nevzat İstar Arıman } \\
\text { (CHP İdare Heyeti ve } \\
\text { Belediye üyesi) }\end{array}$ & İzmir \\
\hline $\begin{array}{l}\text { Ayşe Şekibe İnsel } \\
\text { (Çiftçi) }\end{array}$ & Bursa & $\begin{array}{l}\text { Ferruh Gürgüp (CHP İdare } \\
\text { Heyeti Üyesi) }\end{array}$ & Kayseri \\
\hline $\begin{array}{l}\text { Huriye Öniz Baha } \\
\text { (Öğretmen) }\end{array}$ & Diyarbakır & $\begin{array}{l}\text { BedizBahire } \\
\text { AydilekBelediye Üyesi (Bolu) }\end{array}$ & Konya \\
\hline
\end{tabular}

2 Türkiye'de öğretmenlik mesleği kadınlar için en eski geleneksel ve kamusal niteliğe sahip alanlarından biridir. Öyle ki kadın ögretmen, Osmanlı'dan Cumhuriyet'te "medeniyete geçiş projeleri" kapsamında hep önemli figürlerden biri olmuştur. 


\begin{tabular}{|l|l|l|l|}
\hline $\begin{array}{l}\text { Fatma Şakir Memik } \\
\text { (Doktor) }\end{array}$ & Edirne & Mihri İffet Pektaş (Öğretmen) & Malatya \\
\hline $\begin{array}{l}\text { Esma Nayman } \\
\text { (Belediye Meclis Üyesi } \\
\text { - Öğretmen) }\end{array}$ & Seyhan & Meliha Ulaş (Öğretmen) & Samsun \\
\hline $\begin{array}{l}\text { Sabiha Hatice Görkay } \\
\text { (Öğretmen) }\end{array}$ & Sivas & Seniha NafızHızal (Öğretmen) & Trabzon \\
\hline
\end{tabular}

(Bulut ve Vurmay, 2017; 9; Özer, 2013: 156-157; Gökçimen, 2008:23; Göksel, 1992: 936; Hamzaoğlu, 88; Çanak, 2016:32).

Türkiye Cumhuriyeti kurulduktan sonra yapılan tek partili seçim dönemlerinde kadınlar yapılan seçimlere aşama aşama katılabilmişlerdir. Cumhuriyet rejimi erkek egemenliği üzerine değil erkek-kadın eşitliğini hedefleyen bir anlayışı a sahiptir. Dolayısıyla yaygın olan erkek egemenliği algısını ortadan kaldırıp, erkeklerle eşit haklara sahip olmak isteyen kadınlar, 5 Aralık 1934'te 2598 Sayılı Kanunuyla seçme seçilme hakkına sahip olmuştur. Bu kanunla "seçimlere 22 yaşını bitirmiş her Türk katılabilir" maddesinde yapılan değişiklikle, hem kadınların siyasete girebilmesinin hem de siyasi hayatta söz sahibi olabilmesinin yolu açılmıştır (TBMM ZC, IV/25,1934: 82-85). Kadınlar, 1935 yılında yapılan genel seçimlerde 399 milletvekilliğinin 18'ni (Hatice Özgener 1936 ara seçimlerle meclise girmiştir), 1939 seçimlerinde 429 milletvekilliğinden 16'sını, 1943 seçimlerinde ise 455 milletvekilliğinden 16'sını alarak parlamentoya girmişledir. Çok partili hayata geçilen 1946 seçimlerinde 454 milletvekilliğinin 9, Demokrat Parti'nin iktidara geldiği 1950 seçimlerinde ise 472 milletvekilinden 3 kadındır. İlk defa, farklı partilerin girdiği bu dönemde Meclise giren kadın milletvekillerinden Nazlı Tılabar Demokrat Parti'den, Tezer Taşkıran Cumhuriyet Halk Partisinden, Halide Edip Adıvar ise bağımsız olarak Meclis'e girmiştir. ( TBMM Albümü, 1994: 96112;TBMM Albümü, 1939: 1-123; TBMM Albümü, 1943: 1-120; TBMM Albümü, 1946:1-117; TBMM Albümü, 1950: 1-113). Bu sayı, kadın milletvekilliğine cumhuriyetin ilk yıllarında ne kadar önem ve isteğin olduğunu göstermesi bakımından önemlidir (Doğramac1, 1992: 911; Yıldız, 2012:126: Göksel, 1992: 934; Feyzioğlu, 1992: 895). Öyle ki ilk katıldıkları 1935 seçimlerinde kadınların sayı meclisin \% 4,5'ine tekabül etmiştir. İlginçtir ki o y1llar için oldukça iyi kabul edilebilecek bu sayıya sonraki yıllara kadar ulaşılamamıştır (Oruç, 2010: 103; Gökçimen, 2008: 22).

Dönemin gazete haberlerine bakıldığında da verilen seçme ve seçilme hakkının Türk kadınlarını çok sevindirdiği anlaşılmaktadır. Cumhuriyet Gazetesi 5 Aralık 1934'te "Türk kadınına mebus seçme ve seçilme hakkının verilmesi, Fırkanın Meclis Grubunda kabul edildi" başlığı ile verirken (Cumhuriyet, 5 Aralık 1934), bir gün sonra Meclisin kadın mebus seçme seçilebilmesini "Türk kadını haklarının en büyüğünü aldı" " Türk kadını sevinç ve heyecan içinde" başlıkları ile vermiştir (Cumhuriyet, 6 Aralık 1934, s.12). Milliyet Gazetesi'nde kadın milletvekillerinin TBMM'de ilk kez yer aldıkları 1 Mart 1935 tarihli toplantıyı, en ince ayrıntılarına kadar şu cümlelerle kaleme almıştır: "Saylav bayanlarımızın da iştirak ettiği bu 
meclis toplantısı tarihi bir manzara arz ediyordu. Kadın saylavlar salonun muhtelif köşelerinde yer almışlardı. Sade ve zarif giyinmiş tarzları göze çarpıyordu. Ekseri siyah kumaştan kostüm tayyör, beyaz ipekten bluz giymiş ve siyah papyon takmıştı. Ankara saylavı Bayan Hatı Çırpan koyu mavi memleket kumaşından bir elbise giyiyordu. Şehirli arkadaşları arasında hâkim ve olgun tavırları onu onlardan hiç ayırmıyordu. Bayan saylavlar kürsüye çıtıkça ve yeminden sonra kürsüden ayrılırken çok alkışlandılar. Bayan saylavlardan ilk yemin eden Afyon saylavı Mebrure Gönenç oldu” (Milliyet, 2 Mart 1935: 318).

Aynı zamanda Türkiye'nin her yerinden Ankara'ya telgraflar ve mesajlar yollanmıştır. $\mathrm{Bu}$ hareket o günlerde kadın milletvekillerine değer veren bakışı göstermesi bakımından çok önemlidir. Dönemin önemli yazarlarından Falih Rıfkı Atay "büyük bir devrim yaşandığını ve kendi öz mayası ile yeni bir ulusal varlığın yoğrulduğunu" ifade etmiştir. Aynı zamanda erkeklerin de kadınların bu başarılarına sevindiklerini vurgulayarak; kadınların haklarına kavuşmasını "milyonlarca kolun, kafanın yardımına kavuşması" olarak tanımlamıştır (Ulus, 7 Aralık 1934, Uzun, 2017: 79).

Atatürk'ün manevi kızı Afetinan da "kadınların siyasal haklardan yoksun olduğu sürece yurtta demokratik yönetim kurallarının öğretilmesinin zor olduğu" fikrini savunmuş ve her eserinde bu konuya değinmiştir(Oruç, 2010: 103). Kadınların siyasal haklarını elde etmesinde önemli rol oynayan Türk Kadınlar Birliği 1935 yılında Uluslararası Kadın Kongresine ilk defa ev sahipliği yapmıştır. Böylece daha sonraki yıllarda kadınlar yalnızca toplum içinde erkeklerle eşit olmanın yanında, ülke siyasetinde de etkin rol oynama firsatı bulmuştur. Bu gelişme Türkiye'nin çağdaşlaşma hareketi içinde en önemli adımlarından biri olarak görülmüştür (Oruç, 2010: 103; Demir ve Yüksel, 2017: 235).

Dünyadaki diğer ülkelere bakıldığında, 1893'te Yeni Zelanda'da, 1902' de Avustralya'da, 1906'da Finlandiya'da,1913'te Norveç'te, 1920'de Moğolistan ve ABD'de 1928'de Birleşik Krallıkta bu haklar verilmiştir. Daha yakın tarihlerde ise 1945 'te Japonya ve Fransa'da, 1971'de İsviçre'de verilmiştir. Aslında 1870'lerden 1923 yılına kadar yaklaşık 100'e yakın örgüt kurmuş, 30'dan fazla dergi yayımlamış bir kadın hareketinin 1934'de seçme ve seçilme hakk1 elde etmesi erken bir tarih değildir. Üstelik kadınlara seçme ve seçilme hakkı söylendiği gibi armağan edilmemiş, aksine Cumhuriyet'in kadınları bu ve benzeri hakları Cumhuriyet döneminde vermiş oldukları ciddi mücadeleler neticesinde elde etmişlerdir. (Demir, Y. ve Yüksel, R.F. 2017: 230). Türk kadınlarının, kendilerine tanınan hakları bir mücadele vermeden kolayca elde ettiklerini söyleyenlere Atatürk'ün TBMM kürsüsünden şu sözlerle cevap vermiştir. "Türk kadınına bu hakkın bir lütuf olarak verildiği kanaatinde değiliz. Kimse bu kanaatte olamaz. Bir memleketteki, yurdun her tarafı istilaya uğradığı zaman, kadınlar ateş altında erkeklerle beraber omuz omuza çalışırlar, elbette bu varlıkların yurdun her köşesinde ve her tabakasında söz söylemeye hakları vardır" (Feyzioğlu, 1992: 890). Bunun yanında kadınların seçme ve seçilme hakkının Türk kadınlarına bazı Avrupa ülkelerinden yaklaşık yarım yüzyıl önce verilmesi de çok önemli bir olaydır (Göksel,1992:936; Feyzioğlu, 1992: 895).

Afet inan Medeni Bilgiler kitabında bu konu ile ilgili “I. Dünya Savaşı'ndan sonra birçok ülke kadınların seçim yetkilerini kabul ettiğini ancak Fransa, İtalya, İspanya 
gibi Latin ülkeler bu yetkileri reddederken Amerika, İngiltere, kuzey Avrupa ülkelerde kadınlar seçim yetkilerini kullanmaktadırlar.” demiştir (Afetinan, 2000: 112).

Ancak Türkiye Cumhuriyeti'nde genel nüfus oranlarına bakıldığında çok az sayıda kadın TBMM'ye girmiştir. Örneğin; Meclise giren kadın milletvekillerinin sayısına yıllara göre bakıldığında ilk seçimlerde; 1935 'te 18, 1939'da 16, 1943'te 16, 1946'da 9'ken, 1950'den sonraki seçimlerde bu sayı daha da azalarak devam etmiştir. Bu durumun aksine seçimlere katılımda Türk kadını erkeklere oranla çok daha katılımcıdır. İstatistiki verilere göre yapılan 1954 seçimlerinde katılanların \% 47.8 erkek, \% 52.16 kadındır. 1963 'te bu oran yaklaşık aynı düzeyde kalmıştır. (Göksel,1992:936; Feyzioğlu, 1992: 895).

\section{2-Türk Kadını Ve Atatürk}

Kurtuluş Savaşı'nın gerek hazırlık aşamasında gerekse savaş sırasında Türk kadınının yapmış olduğu hizmetlerin önemi tartışma götürmez ölçüde büyüktür. Bunu iyi bilen Mustafa Kemal Paşa Kurtuluş Savaşı'nı verirken güç aldığı, yardımını gördüğü Türk kadınını hiç unutmamıştır. Vefa duygusunu her firsatta belirtmiştir. Cumhuriyet dönemi boyunca kadın haklarına öncelik tanınması ve çok önem verilmesinde bu duygunun etkisi büyük olmuştur (Gül, 1998:79; Göksel, 1992:920; Çanak, 2016: 28).

Öyle ki yaptığı çalışmalarda (okumalarda) Meşrutiyet döneminin bütün düşünce akımlarını inceleyen Atatürk Türk kadınının "ikinci sınıf" insan durumundan kurtarmanın zorunlu olduğu sonucuna ulaşmıştır. "Yüzyıllardır yarım tedbirlerle ne hukuk ne eğitim çağdaşlaşabilir, ne Türk kadını ne de ülke kurtarılabilirdi” bu düşüncesinden hareketle "tek bir çıkış yolu vardı. Devlet yapısını, eğitimi, hukuku, kadının statüsünü laikleştirmek, kimsenin dini inancına ve vicdan hürriyetine karışmadan din ile devleti, din ile hukuku ayırmak aklın ve çağın gerektirdiği yola girmek"te olabileceğini işaret etmiştir" (Feyzioğlu, 1992: 887; Doğramac1, 1992:902; Göksel, 1992: 920).

Atatürk, Türk kadınına kendine özgü bir anlayışla gereken önemi vermiş ve bunu çeşitli nedenlerle yapmış olduğu yurt gezilerinde açık bir dille ifade etmiştir. Kadının başta eğitim olmak üzere, hukuk, çalışma hayatı, siyasal katılım, toplumsal yaşamda ve aile yaşamında eşit haklara sahip olarak yerini alması için gereken tüm atılımlar yapılmış ve mümkün olan en kısa zaman içinde gerçekleştirilmiştir. (Çanak, 2016: 159).

Bir yurt gezisinde Mustafa Kemal Paşa Türk kadınını şöyle tanımlamıştır;

"Türk kadını savaş sırasında ülkeye çok büyük yardımda bulundu; herkes gibi o da acı çekti. Bugün o özgür olmalıdır, eğitim görmeli, okullar kurmalı, ülkede erkeklere eşit bir konuma sahip olmalıdır. Buna hakk1 vardır."(Caporal, 1982:180)

Paşa, Ocak 1923 'te İzmir'de yaptığı bir konuşmada da özellikle kadın ve erkeğin kalkınmada birlikte yer almaları için şunları söylemiştir; 
"Şuna inanmak gerekir ki, yeryüzünde her şey kadınlar tarafından yapılmıştır. Bir toplum onu oluşturanlardan yalnız birinin ihtiyaçlarının kazanılması ile yetinirse, o toplum yarıdan çok güçsüzlük içinde kalır... Bir millet ilerlemek ve uygarlaşmak isterse, özellikle bu noktayı temel alarak benimsemek zorundadır. Kadınlarımız da bilgili olacak ve erkeklerin geçtiği tüm öğretim derecelerinden geçeceklerdir. Sonra kadınlar, toplumsal hayatta erkeklerle birlikte yürüyerek birbirlerinin yardımcısı ve destekçisi olacaklardır. Memleketimizde cahillik varsa bu yaygındır. Yalnız kadınlarımızı eğil, erkeklerimizi de kapsamaktadır... Son olarak diyorum ki, bizi analarımızın adam etmesi gerekirdi. Onlar edebilecekleri kadar etmişlerdir. Ancak bu günkü seviyemiz, bu günün gerektirdiği zorunluluk ve ihtiyaçlara yeter değildir. Başka zihniyette, başka olgunlukta adamlara ihtiyacımız var. Bunları yetiştirecek olanlar da bundan sonraki annelerdir." Görüldüğü gibi Atatürk, daha Cumhuriyet ilan edilmeden önce kadınların geleceği ile ilgili her firsatta olumlu fikir beyan etmişti. Bu bağlamda İnebolu'da yaptığı bir konuşmada ciddi bir usavurmaya dayanmadan kadınlara dayatılan bütün gelenekleri bırakmak gerektiğinin altını çizmiştir (Atatürkçülük I., 1998:334; Sağ 20; Doğramac1, 1992: 903).

1923 yılında yaptığ kadınları ve erkekleriyle yürümezse ilerlemesine ve medenileşmesine teknik bakımdan imkân ilmi bakımdan da ihtimal yoktur". (Atatürkçülük I., 1998:335; ; Feyzioğlu, 1992: 888) diyerek kadın erkek eşitliğinin altını çizmiştir. Atatürk'ün, 1923 yılında İslam dininin kadına bakış açısını da şu sözleriyle anlattı̆ğ görülür.

“ Bizim dinimiz hiçbir zaman kadınların erkeklerden geri kalmasını istememiştir. Allah'ın emrettiği şey, Müslüman erkek ve kadın beraber olarak ilim ve irfan kazanmasıdır. Kadın ve erkek bu ilim ve irfanı aramak ve nerede bulursa oraya gitmek ve ona sahip olmak mecburiyetindedir. İslam ve Türk tarihi incelenirse görülür ki bugün kendimizi bin türlü kayıtlarla bağlı zannettiniz şeyler yoktur. Türk toplum hayatında kadınlar ilim ve irfan bakımından diğer unsurlar da erkeklerden kesinlikle geri kalmamışlardır. Belki daha ileri gitmişlerdir”.(Atatürkçülük I., 1998: $335)$.

Atatürk 28 Ağustos 1925 'te İnebolu'da konuşmasında, giyim, şapka ve Türk kadınından söz ederek, ülkenin geleceğinin ve çağdaşlığının kadınların dünyaya açılmasıyla mümkün olacağını ve ülkenin esenliği ve çağdaşlığını kadınların dünyaya açılmasında gördüğünü ifade etmiştir. Hemen sonrasında aynı konuda 30 Ağustos 1925 günü Kastamonu'da yaptığı konuşmasında ise kadın hakları ile ilgi Atatürk;

"Bazı yerlerde görüyorum ki kadınlar, yüzünü gözünü gizliyor ve yanından geçen erkeklere karşı ya arkasını çeviriyor veya yere oturarak kapanıyor. Bu tavrın anlamı nedir? Efendiler medeni bir milletin anası, millet kızı bu garip şekle son vermelidir.... Şüphe yok ki ilerleme adımları, iki cins tarafından beraber, arkadaşça atılmak ve ilerleme yeniliklerle birlikte, merhaleler aşmak lazımdır. Böyle olursa, inkılap başarılı olur. Herhalde daha cesur olmak lüzumu açıtır." demiştir (Gül,1998:80 Sağ,2001:21).

Atatürk'ün 1923-1926 y1lları arasında yurdu dolaşarak halkı kadın hak ve statüleri konusunda yapacağı büyük değişikliğe hazırlamasından sonra en önemli gelişme 17 Şubat 1926 günü “Türk Medeni Kanunu”nun kabulüdür. Bu kanunla Türk 
vatandaşları ayrım yapılmaksızın diğer uygar ülkelerin vatandaşları gibi eşit haklara kavuşmuşlardır. (Bulut ve Vurmay, 2017; 7-8; Gündüz, 2000:238; Feyzioğlu, 1992: 891 )

Bu yıllarda kadınlar kurdukları Kadınlar Hak Fırkası ve Türk Kadınlar Birliği Cemiyetleri ile ısrarla siyasi haklarını elde etmeye çalışarak hemen hemen her seçim sürecinde bu mücadeleden vazgeçmediklerini göstermişlerdir. Türk kadınlarının "Seçme ve Seçilme Hakkı" ile ilgili ilk temasının 1926'da Trabzon Türk Ocağında Süreyya Hulusi isminde bir hanımın verdiği konferansta bu konuyu ifade etmesiyle atıldığı söylenebilir (Göksel, 1992: 934).

Ancak Cumhuriyet'in ilk yıllarında toplumunun yapısı kadını meclis kürsülerinde görecek kadar olgunlaşmamıştır. Mustafa Kemal Atatürk'ün her konuşmasında yer bulan Kadınlara seçme ve seçilme hakkının devrimlerin ileri aşamasında verilmesinde acele etmemesi muhtemelen bu sebeptendir ${ }^{3}$.

Atatürk'ün bu konudaki desteğini 1975'te Türk Kadınları Kültür Derneği'nde konferansında eski İzmir Milletvekillerinden Perihan Arıburun bu konu ile ilgili bir anısını şöyle anlatır;

"1934 yılında bir gün Çankaya Köşü̈nden kendisine ve annesi Makbule Eldeniz'e (Atatürk'ün hocası merhum Naci Eldeniz Paşa'nın eşi) telefon mesajı gelir. Belli bir günde Ankara Türk Ocă̆ı'na gelmeleri istenir o gün Ocak salonunda Ankara'nın bütün aydın kadınlarının bir araya getirildiği görülür. Bu kapalı salon toplantısında seçkin konuşmacılar Türk kadınına da milletvekili seçilme hakkının verilmesini isteyen hararetli konuşmalar yaparlar. Sonunda Türkiye Büyük Millet Meclisi'ne kadar bir gösteri yürüyüşü yapılmasına karar verilir ve hemen uygulamaya geçilir.

Aydın bir kadın topluluğunun meclis önünde yüksek sesle konuşmalarını çalışma odasında bulunan ve olayı hiç bilmeyen (!) Atatürk haber alır. Çevresindeki milletvekillerine "Bakın bakalım hanımlarımı ne istiyorlar? Bana da bilgi getirin" der. Gidip konuyu inceleyen mebusların telaşlı halleri karşısında Atatürk: "Arkadaşlar! Kadınlarımız Mecliste görev isteğinde haklıdırlar. Hemen kanun tasarısı için çalışmalara başlayınız”.

Gazi Paşa'nın bu direktifleri ile çalışmalar başlar, önce Teşkilatı Esasiye Kanunu'nun 10. ve 11. maddeleri değiştirilir. 5 Aralık 1934'te kabul edilen bu değişiklikle kadınlarımıza milletvekili olmak için seçme ve seçilme hakkı tanınır. Böylece Türk kadınının Türk erkeği ile tam manası ile eşit düzeye gelmesi sağlanmış oldu. Olay dünya çapında yankılar yaratarak, birçok ileri ulusun kadını bundan örnek alma çabasına girmiştir. Yenilenen genel seçimlerden sonra 1 Mart 1935

\footnotetext{
${ }^{3}$ Atatürk Türk kadınının hakları üzerine ne zaman bir yeniliğe adım atmak istese karşısında tam ve koyu bir taassupla karşılaşmıştır. Ancak her seferinde konuşmalarında kadınlarla ilgili görüşlerini açıklamaktan da geri durmamıştır. Öyle ki Osmanlı'dan kalma bir seçim kanunun kullanıldığı ve bu yasaya göre Teşkilatı Esasiye Kanunun 20 bin nüfusa bir milletvekili seçilmesini emreder. İstiklal savaşının sürdüğü bu dönemde erkeklerin çoğu cephededir. İstenir ki, kadınlar da vatandaş sayılsın bu rakamın içine girmiş olsun. Ancak bu kanun teklifi Bolu Mebusu Tunalı Hilmi Bey tarafindan TBMM'ye gelince kızılca kıyamet kopmuştur.
} 
tarihinde ilk kadın milletvekillerimiz Türkiye Büyük Millet Meclisi'nde kendilerine ayrılan yerlere oturmuşlardır (Göksel, 1992: 935).

1935 y1lında "Siyasi ve sosyal hakların kadın tarafindan kullanılmasının, insanlığın mutluluğu ve prestiji açısından çok gerekli olduğuna eminim" diyen (Atatürkçülük I., 1998:333; Atatürkçülük III., 1998:157), Atatürk Türkiye'nin "muasır medeniyet" seviyesine çıkmasında Türk kadınına öncü bir rol vermiştir.

Türk kadını için bu derece ulvi bir misyon yükleyen Atatürk’ün kadın ve kadın hakları ile ilgili düşünce ve fikriyatının şekillenmesinde elbette ki kendi ailesi ve aile yaşantısı ve ilişkileri ile ilgili duygu ve düşüncesinin de önemli etkisi olmuştur. Zira Atatürk'ün annesi ve kız kardeşine olan bağlılığı ve sevgisinin bunda etken olduğunu söylemek mümkündür.

Ayrıca Atatürk'ün genel anlamda insana bakışında evrensel ölçütlerin önemli yer tuttuğunu görüyoruz. Nitekim Atatürk kadın erkek ayırımını ortadan kaldırarak hepsini "insan" kelimesinde toplamayı hedeflemiștir. (Doğramac1, 1992: 902). Atatürk'ün şahsına ait kadın anlayışı, Birleşmiş Milletler teşkilatının kabul ettiği, bugün de dünya kadınlarının üzerinde birleştiği ve yaymaya çalıştığı bir konudur. $\mathrm{Bu}$ da onun her konuda olduğu gibi bu konuda da ne kadar uzak görüşlü bir lider olduğunu bir kez daha kanıtlamıştır (Doğramac1, 1992: 903). Aynı zamanda kadınların ekonomik hayatın yanında eğitim ve siyaset alanında da yer almalarının ülke için ne kadar önemli olduğunu da her firsatta belirtmiştir. Ülkenin ilerlemesini kadın-erkek eşitliği ile bilimin 1şığında gören Atatürk, reformlarını bu minval üzerinde yapmıştır.(Gül, 1998:83). Böylece Türk kadınları çok kısa bir sürede yaşamın her alanında başarılı bir statüye gelmiş ve birçok Avrupa ülkesinden daha önce emeğinin karşıllğını alabilme imkânına sahip olmuştur (Doğramacı, 1989:136; Sağ, 2001: 19- 21).

\section{3-İlk Kadın Milletvekillerinden Mihri İffet Pektaş 3.1. Hayatı}

Mihri İffet Pektaş TBMM Azasına mahsus kısa tercüme-i hal için el yazısıyla doldurduğu özgeçmiş formuna“1311 (1895) Şubat'ında Bursa'da doğdum” diye yazmıştır (TBMM Arşivi Devre: V, No: 271). Ancak TBMM Arşiv kayıtlarında VII. Devre Meb'us seçilmiş olanlara ait mazbatada ise doğum tarihini 1893 olarak verilmiştir ${ }^{4}$. Eski Bursa Vali Muavinlerinden Yusuf Bahattin Bey'in kızı olan Mihri İffet Pektaş'ın annesi İclâl Hanım, kardeşleri Şukufe (Kunter), Halide (Sözer) ve Ziver Bey'dir. Mihri Pektaş, ilköğrenimini Zühtü Paşa Mektebi'nde almıştır. Bu okuldan 1907 y1lında mezun olduktan sonra 1908 y1lında Amerikan K1z Koleji'ne başlamış ve bu okulu da 1916'da bitirmiştir ( TBMM Arşivi Devre: V, No: 271;

\footnotetext{
${ }^{4}$ Bu konu ile ilgili Sadık Sarısarman "Malatya'nın İlk Bayan Milletvekili Mihri İffet Pektaş ve TBMM'deki Faaliyetleri” adlı makalesinde Mihri İffet Pektaş'ın doğum yılı 1886 olarak verilmiştir.
} 
TBMM Arşivi, Kutu: 42, Dosya: 943; Parlamento Tarihinde Kadın Parlamenterler, 2009: 326; Güneş, 2009: 524; Yıldız, 2012:102)5.

Mihri Pektaş yazar Deniz KAYNAK ${ }^{6}$ 'a verdiği röportajda kendini ve okul hayatını şu sözlerle anlatır:

“ 1895 'te, babamin memur olarak bulunduğu Bursa'da dünyaya geldim. Fakat İstanbul'a çok küçükken dönmüşüm. Bütün hayatım burada geçti... Ilk önce beni babam okuttu, ilk gittigim mektep Kızlltoprak'taki Zühtü Paşa iptidaisi idi. Sarıklı hocaların falaka ile okuttuğu bu mektep, tam tipik bir mahalle mektebiydi. Birçoğumuzun hayatina giren bu mahalle mektepleri, o stralarda memleketin en yoksul, kirli çocukları ile omuz omuza geçirdiğimiz mektep hayatları da gösteriyor ki, biz Türkler, yaradılış itibarıyla, demokratll̆̆ inkâr edilmez bir milletiz. Meşrutiyet ilan edilince, o sene, Koleje girdim ve birinci sınıftan başlayarak sekiz sene orada okudum. Bunlar hayatımın hem en tatl, hem en acl günleri idi...

"Türk hocalarım, strastyla, Nakiye, Tevfik Fikret, Fazll Ahmet ve Riza Tevfik'ti... Bayan Nakiye ilk seneme tesadüf eder. Bu siyah çarşafl, tatlı sesli, zayıf genç kadınla bir gün gelip de Türk kadınlığını ve Türk milletini Milli Mecliste beraber ve ilk olarak temsil etmek şerefinin bizim payımıza düşeceğini, eminim ne o, ne de ben düşünmemişizdir. Bende ve hepimizde en uzun ve en derin tesir, Fikret'inki olmuştur. O zaman Kolejdeki Türk kızları çok değildi. On beş, yirmi kişi var, yoktu. Kimimiz Dam du Siyondan, kimimiz rüştiyeden, kimimiz idadiyeden, kimimiz de ya iptidaiyeden, ya doğrudan doğruya evimizden geliyorduk. Bu karmakarışı sinıfi Fikret, o engin şahsiyeti ile adeta hipnotize ederek idare ederdi. Ne okurduk, ben de bilmem! Herhalde mevzu, başımızdan epey yüksek olacak. Fakat şimdi düşündü̈̆̈̈m vakit görüyorum ki hafizamda canlanan bir ylğın beyit ve misra kirıntılar ile bu adam, bize her şeyden evvel okumak ve okuduğumuzu duyarak tatmak zevkini vermişstir... Eskilerden Fuzuli, Nedim, sonra bilhassa Hamit, Ekrem ve Cenap: Bu karmakarlşık ses, renk ve imaj akıntısının yarattığ bir memleket nostaljisi... Bir kere, Fikret'in tesirine kapllan, kolay kolay kurtulamaz. Sesi güzel, kendi güzel, üstü daima temiz, bütün manasiyla centilmendi: 'Insan pürüzsüz olmalı!' dediğini çok iyi hatırlarım. Kendisi de bize hakikaten pürüzsüz gözüküyordu. Bu, Fikret'in son seneleri, uzun hastalı̆̆ının kendisini için için yiyip bitirdiği senelerdi. Onun için daima çok act, titiz ve bedbindi ve bizi biraz hirpalardı. Fakat biz kendisini yine severdik...

Dört sene büsbütün yattl ve yerine Fazll Ahmet'i gönderdi. Bunlar, harbin kötü seneleriydi. Bay Fazll Ahmet, Arnavutköyü'nün tepesine ancak vakit buldukça uğruyor ve bize doyulmaz saatler yaşatıyordu.

\footnotetext{
5 Mihri İffet Pektaş TBMM Azasına mahsus kısa tercüme-i hal için el yazısı ile doldurduğu özgeçmişinde Amerikan Kız Kolejinde sekiz yıl okuduğunu birinci dereceden Şehadetname ile mezun olduğunu yazmıştır.

6 Bu röportaj 30 EYLÜL 2013 de 5 Harfliler elektronik dergisinde yayımlanmıştır. http://www.5harfliler.com/malatya-mebusu-bayan-mihri-pektas/2 21.11.2018 sitesinden alınmıştır.
} 
Zorla geldiği muhakkaktı. Sinıflarda ancak, kendi tabirince "Kozöri" yapabiliyorduk. Fakat ona tahrir vazifesi yapmayl çok isterdik. Çünkü tenkidi o kadar hoștu. Bize kendi kendimize gülmesini ögretmiş, aynı zamanda Yahya Kemal'i de tanıtmıştı. Yazlk ki bir sene kaldı ve yerini Rıza Tevfik'e bırakarak çekildi.

Bu sonuncu bize sözde tarih okutacaktı: Her gün sultan Osman'dan başlıyor, Selim'e gelip dayanıyordu! Ondan öteye bir adım atamadık. Tatl söylemekle beraber, mevzuu öyle bir dağıttyordu ki... Hepimiz gayret etsek toparlayamazdik. Sinufta laubalilik son dereceyi bulmuştu. Bize erikler, şekerler getiriyor, kazara azarlayacak olsa, talebe kendisine küsüyordu. Barışmak için, elinde bir kutu şokola, koridorlarda dolaşıp durduğunu görürdük. Yalnız tekke edebiyatının zevkini kavramıs bir adamdl. Bu zevki bize de vermiştir." (http://www.5harfliler.com/malatya-mebusu-bayan-mihri-pektas)

Kolejden mezun olduktan sonra kendi okulu olan Amerikan Koleji'nde 1916-1918 yılları arasında Türkçe öğretmenliği yapan Mihri İffet Pektaş daha sonra 1920-1921 yılları arasında Bezmi Âlem Kız Lisesi’nde İngilizce öğretmenliği, 1923-1935 yılları arasında da Robert Koleji'nde İngilizce öğretmenliği yapmıştır ${ }^{7}$. (TBMM Arşivi Devre: V, No: 271; Günay, 2007: 521; Güneş, 2009: 524; Yıldız, 2012:101).

Mihri Pektaş Hanım 1917'de Hüseyin Hulusi ${ }^{8}(1883-1970)$ Bey'le evlenmiş, Fatma Necla $\left(\right.$ SOYAK $^{9}$ ) ve Fatma Süveyde (SOYAK) adlarında iki kız çocukları olmuştur (Güneş, 2009; 524; Yıldız, 2012:102).

Mihri Pektaş meslek hayatı ile ilgili ise Deniz KAYNAK'a verdiği aynı röportajda: "Mektep hayatının neden tatl olduğunu söylemeye hacet yok. Acl olmasinin sebebi, tahsil hayatımıza, hem Balkan harbinin, hem de Umumi harbin karlşmasindan ileri geliyordu. Şüphe yok ki, kozmopolit bir muhitte böyle seneler daha acı, daha güç geçer! Belki zamanın, belki de babamla hocalarımın tesiriyle biz çok idealisttik. Birçok şeyler yapmaya hazırlanıyor, muhitimizin bizi kollarını açarak beklediğini tahmin ediyorduk. Meğerse aldanmışı!!1916'da mektebi bitirdim, daha

\footnotetext{
7 İlk kadın milletvekillerinden asıl mesleği öğretmen olanlar; Mebrure Gönenç, Türkan Örs Baştuğ, Sabiha Gökçül Erbay, Hatice Özgener, Huriye Öniz Baha, NakiyeElgün, Fakihe Öymen, Bahire Bediz Morova Aydilek, Mihri Bektaş, Meliha Ulaş, Esma Nayman, Sabiha Görkey ve Seniha Hızal'dır (Gökçimen,2008: 24).

${ }^{8}$ Mihri Pektaş'ın eşi Hüseyin Pektaş 1884 yılında Rumelihisarı, Sarıyer, İstanbul'da doğdu. Yeniköy Belediyesi Vergi Kâtibi Yusuf Bey ile Şehitlik Dergâhı Şeyhi Nafi Baba'nın kızı Hayriye Hanım'ın en büyük çocuğudur. 1903 yılında Robert Kolej'ini bitiren ilk Türk öğrencilerinden biridir. Yüksek eğitimini Sorbonne Üniversitesi Tarih Bölümünde yapmıștır. Robert Kolej'inde 1905 yılında Tarih, Türkçe ve Edebiyat öğretmenliği yaptı. Ayrıca Yüksek Ticaret ve Mülkiye mekteplerinde İngilizce öğretmeni olarak görev yapmıştır. Tevfik Fikret'ten edebiyat, Arapça ve Farsça dersleri almış alan Hüseyin Pektaş, onun hasta olduğu günlerde Robert Kolej'de yerine derslerine de girmiştir. 1923 y1lında Lozan Barış Konferansının her iki devresinde de, Türk Heyeti'nin tercüman kâtipliğini yapmıştır. 1917 yılında Mihri Pektaş ile evlenmiştir Hüseyin Pektaş 13 Kasım 1970, İstanbul'da eşinden dokuz y1l önce vefat etmiştir.

${ }^{9}$ Necla (1928) ve Süveyda (1929) adlı iki kızları, Atatürk'ün Genel Sekreterliğini yapan, TBMM V. Dönem Burdur Milletvekili Hasan Rıza Soyak'ın oğulları Enver ve Sungu Soyak ile evlenmişlerdir.
} 
şahadetname almadan direktörümüz Doktor Patrik bana Kolej'de kalmamı teklif etti. Fakat babam mutlaka bir Türk mektebinde hocalı etmemi istiyordu. O zaman, Maarif nazırı Şükrü idi. Taşraya gitmeye de hazırdım. Maarif birçok masraf ederek Kollej'de talebe okuttuğu halde kendi hesabina tahsil eden ben, bir türlü bir hocalık bulamadım! Ve neticede Kolej'in teklifini kabul ettim. Ben bundan tabiatiyla memnundum, çünkü o sırada Hüseyin'le nişanlanmıştık ve ikimiz de komşu mekteplerde bulunacaktık. O erkek Kolejinde, ben kız Kolejinde! Babam o yaz öldü̈̆̈̈ için evlenmemiz ertesi seneye kald ve kızım Necla doğuncaya kadar (1918) hocalık ettim. Dört sene sonra çocuklarım büyümüşlerdi, tekrar mesleğe atılarak Bezmialem kız lisesinde bir sene Ingilizce muallimliği ettim, fakat bundan sonraki meslek hayatım asıl Robert Kolej'de geçmiştir. On üç sene bu mektepte kaldım ve talebelerim duymasin ama erkek talebeyi kuzlara tercih ettim. Ancak, ben muallimliği çok severek yaptım. Fakat ideal hoca olmadığımı tahmin ediyorum. Çünkü bir zaafim vardl: Sinufta en tembel talebe kimse ona musallat olur, iyi talebe ile meşgul olmazdım. Pedagojik bir kusur..." diye anlatiyor.

Yine aynı röportajda kadınlarla ilgili ise şunları söylüyor:

"- Böyle iki sinıf var midır? Varsa kimlerdir? Bazı kadın firsat bulmuş, okumuş, bazı kadın mecbur olmuş, çalışmış, bazı kadın şahsiyetini ev haricinde tekâmül ettirmek arzusunu duymuş, bazılarının da 'kısmet'i çıkmış, evlenmiştir. Bütün bu evlenen kadınlar aynı sınıftan mıdır? Her işini kendi gören bir aile kadını ile hiçbir işini kendi görmeyen bir aile kadınını nasıl aynı sınıfa koruz? Hayatta çalışanlarla çalışmayanlar, çalışmaya mecbur olanlarla olmayanlar, çalışmayı sevenlerle sevmeyenler vardır: Kadın olsun, erkek olsun! Mesela, kadın benliğinin uyanmasında ve şahsiyetini tekâmül ettirmeye müsait muhit bulmasindadir ve her memlekette biraz geri, biraz ileri, fakat muhakkak surette cereyan budur. Her kadın, istediği erkeği bulunca derhal evlenir ve evine, çocuklarına bütün varlığını hasreder. Bu, onun bir saadetidir. Fakat ayn zamanda her kadın, okumak firsatını bulursa, mutlaka şahsiyetini tekâmül ettirmek için kiler ve dikiş haricinde bir saha bulur, daha genişler. Buna hiçbir kuvvet mani olamaz ve olmamalıdır da... Zaten feminizm nedir? Erkekle kadının müsavi oldukları iddiası değil, kadına insanlık ve vatandaşlık hususunda müsavi haklarının verilmesi davasıdır. Yoksa tabiatın vermediği bir müsavatı (eşitliği) insanlar nasıl yaratabilir? — Kadın dahi olamazmış... Varsın olmasın! Fakat doktor olmak istiyorsa, olabildiği kadar, yani bir Mediyokr (ortalama) doktor da o olsun... Görüyorsunuz, Madam Küri'den falan bahsetmiyorum. Kadınların iş buhranı çıkarıyor meselesineKadınların çalışmasının işsizliğe sebep olması iddiası boştur. İssizlik kadının çalıştığı sahalarda değildir. Bilakis kadının kazanıp getirdiği para, o ailenin istihlak kabiliyetini artırır ve ailelerin istihlak kabiliyeti ne kadar genişse memleketteki fabrika ve tezgahlar da o nispette işler..." diye anlatır (http://www.5harfliler.com/malatya-mebusubayan-mihri-pektas). 


\subsection{Milletvekilliği Dönemi (1935-1946)}

İlk kadın milletvekillerinden Mihri İffet Pektaş, V ${ }^{10}$, VI ${ }^{11}$ ve VII ${ }^{12}$. Dönem TBMM'de CHF Malatya milletvekilliği yapmıştır. V. ve VI. Dönemde Kütüphane ve Sayıştay (Divanı Muhasebat) Encümeni olmuştur. (Güneş, 2009: 524; Günay, 2007: 521). Yeni kurulan Türkiye Cumhuriyeti adına çeşitli toplantılarda görev alan ve uluslararası platformlarda Türk delegesi olarak bulunan Mihri Pektaş, sosyal ve siyasi hayatta o günün önde gelen ilk kadınlarından biridir(Yıldız, 2012:102). 1935 yılında yapılan seçimleri ve Malatya milletvekilleri Malatya basınından Firat Gazetesinde(Kızılkaya, 2016: 89) ${ }^{13}$ şu başlıklarla yer almıştır:

Saylav namzet tespit edildi. Namzetlerimiz

Fırka umum-i başkanlık divanınca ayırt edilen saylav namzetlerin listesi dün (pazartesi) Anadolu ajansina verileceği ve bugün yurdun her yönünde ilan edileceği daha bir gün önceden bildirilmistiti.

Vilayetimiz için ayırt edilen namzetlerin adlarını okuyucularımıza ulaştırmak için dün çıkacak sayımızı bu güne bıraktık. CHF Genel başkanı büyük önder Atatürk'ün Malatya namzetlerini bildirene sabaha doğru alınan telyazısını okuyucularımıza duyururken kıvanç ve sevinç içindeyiz.

Malatya C.H.F. reisliğine:

Vilayetimiz için Fırka umumi başkanlık divanının tespit ettiği saylav namzetlerinin isimleri aşağı da ilan ederim.

KEMAL ATATÜRK

1- ISMET INNÖNÜ. Başbakan ve C.H.F. Başkan vekili

2- Dr. HILMI ORTAÇ. Eski Malatya saylavi

3- MAHMUT NEDIM ZAPCI

4-VASIF

5-MUTTALIP ÖKER

," ,"

, , , ,

6-MIHHRI PEKTAŞ ( kadın) Kolej Türkçe muallimi

7- GENERAL OSMAN NURI KOPTAGEL eski firka kumandanı

8- OSMAN HILLMI TANER. Malatya C. H. Fırkası başkanı

9- EMRULLAH BARKIN. Başbakanlık umumi müdürlerinden

( FIRAT) Eski saylavlarımızı ve onlara katılacak yenileri candan

kutlarken vakit darlı̆̆ından ve yer azlığından ötürü umumi namzet listesini özür dileyerek Perşembeye bıraktı̆̆ını da özür dileyerek okuyucularına bildirir ( Firat, 5 Şubat 1935 Salı: No: 217).

Yine o dönemde Malatya'nın diğer yerel gazetesi Ünal Gazetesi (Kızılkaya, 2016: 89) 14 “ 'MALATYA'NIN YENI SAYLAVLARI” başlığıyla 5 Şubat 1935 Salı günü haber yapmiştır.

${ }^{10}$ V. Dönem milletvekillerinin görev süresi 1 Mart 1935-27 Aralık 1938 arasındadır.

${ }^{11}$ VI. Dönem milletvekillerinin görev süresi 1 Nisan 1939-15 Aralık 1943 arasındadır.

12 VII. Dönem milletvekillerinin görev süresi 8 Mart 1944-14 Haziran 1946 arasındadır.

${ }^{13}$ Fırat Gazetesi 8 Ekim 1935 yılında Malatya'da haftada sadece Pazartesi Perşembe günleri çıkan Cumhuriyetçi ve Halkçı yerel bir gazetedir. Yayım hayatını 27 Eylül 1952'de tamamlamıştır.

${ }^{14} 19$ Ocak 1935 tarihinde çıkmaya başlayan Ünal Gazetesi Malatya'nın günlük olarak yayımlanan Cumhuriyetçi, siyasi havadis veren ilk yerel halk gazetesidir. 1939 yılında yayım hayatına son vermiştir. 
"Fırka Divanınca yeni seçimde Malatya Saylavliğına seçilerek namzetler hakkında Vilayet Saylav Intihap Encümeni Başkanı Belediye reisi Mehmet Tevfik İnönü'ye aşağıdaki teblĭ̆ gelmiştir. Malatya belediyesine vilayetimiz için firka umumi başkanlı $k$ divanının tespit ettiği Saylav namzetlerini aşağıda ilan ederim. General İsmet İnönü Başbakan ve CHF Genel Başkan vekili "Dr. Hilmi Ortaç Malatya Saylavı Mahmut Nedim eski, Malatya Saylavi Vaslf eski, Malatya Saylavı Muttalip eski, Malatya Saylavı Mihri Pektaş (kadın) kolej Türkçe muallimlerinden.

General Osman Nuri Koptagel eski Firka Kumandanı Osman Hilmi Taner Malatya Cumhuriyet Halk Fırkası Başkanı, Emrullah Barkın Başbakanlık umumi müdürlerindendir. Ünal Yeni Saylavları Candan Kutlar ( Ünal, 5 Şubat 1935, Yll. 1, Sayl:18) cümleleriyle okuyucularına duyurmuştur.

\section{2.a. Mihri İffet Pektaş'ın V. Dönem Meclis Çalışmaları}

TBMM V. Dönem seçimlerinde Malatya'dan aday gösterilen Mihri Pektaş, 8 Şubat 1935 Cuma günü merkezde ve 9 kazada yapılan saylav seçiminde 785 oy ile Malatya milletvekili seçilmiştir. 21 Şubat 1935 günü kendisine verilen seçim tutanağıyla 1 Mart 1935'te Meclis'e katıldı ve tutanağ 7 Mart 1935 günü onaylandı ( TBMM Arşivi Devre: V, No: 271; TBMM ZC; V/1: 1935:7, 20; Yıldız, 2012:102).

Frrat Gazetesi Şubat 1935 ’te seçim sonunda seçilen milletvekilleri listesi şu şekilde vermiştir.

Cuma günkü seçimde 785 şer reyle Malatya saylavllğına seçilenler:

1- ISMET INÖNÜ. Başbakan ve C.H.F. Başkan vekili

2- Dr. HILMI ORTAÇ.

Eski Malatya saylave

3- MAHMUT NEDIM ZAPCI

4-VASIF

5-MUTTALIP ÖKER

", ", ",

6-MIHRII PEKTAŞ ( kadın) Kolej Türkçe muallimi

7- GENERAL OSMAN NURI KOPTAGEL eski firka kumandanı

8- OSMAN HILMI TANER. Malatya C. H. Fırkası başkanı

9- EMRULLAH BARKIN. Başbakanlık umumi müdürlerinden (Fırat,

11 Şubat 1935 Pazartesi, No: 219)

Mihri İffet Pektaş'ın Malatya'ya milletvekili olarak Malatya'ya geldiğine dair tek bilgi Malatya'nın o dönem yerel gazetelerinden biri olan Ünal Gazetesinde tespit edilmiştir. Gazete 19 Ağustos 1935 Pazartesi günü "SAYLAVLARIMIZ GELDİ" başlığıyla,

"Saylavlarımizdan Bayan Mihri Pektaş ve Bay Emrullah bu günkü trenle şehrimize gelmiştir. Hoş geldiniz deriz" cümleleri ile okuyucularına duyurmuştur ( Ünal, 19 Ağustos 1935, Y11: , Sayı: 190). 
Malatya'ya ilk defa gelen Mihri İffet Pektaş, diğer milletvekilleri Emrullah (Barkan) ve Hilmi Taner'le birlikte incelemelerde bulunmak üzere ilçelere de gitmişlerdir. Bu haberi Ünal Gazetesi 23 Ağustos 1935 Cuma günü "SAYLAVLARIMIZ ILÇELERIMIZZE GITTILER” başlığıyla şöyle paylaşmıştır.

"Bundan birkaç gün evvel Ankara'dan ilk olarak şehrimize gelen Bayan ve Bay saylavlarımı iki günden beri Bay Hilmi Taner ile birlikte ilçe seyahatlerine çımışlardır. Seyahatten sonra tekrar gelecekleri söylenmektedir" diye yazmıştır (Ünal, 23 Ağustos 1935, Y11:1, Say1:194). Yine aynı gazete iki gün sonra 26 Ağustos 1935 Pazartesi günü “SAYLAVLARIMIZ BUGÜN DÖNECEKLER” başlığının altında

" Inceleme gezisi yapmak üzere ilçelerimize gitmiş olan saylavlarımızdan Mihri Pektaş, Emrullah (Barkan) ve Hilmi Taner bugün şarımıza ( şehrimize) döneceklerdir" diye yazmıştır ( Ünal, 26 Ağustos 1935, Y11:1, Say1:197).

Mihri İffet Pektaş ve diğer milletvekillerinin Malatya'ya dönüşlerini ve Ankara'ya gideceklerini "SAYLAVLARIMIZ GELDI VE ANKARAYA GIDECEKLER" başlığıyla 4 Eylül 1935 Çarşamba günü veren Ünal gazetesi

"Hekimhan ilçesine giden saylavlarımız pazartesi günü akşamı geri dönmüşlerdir. Haber aldığımıza göre saylavlarımızdan bayan Mihri Pektaş ve bay Emrullah 5 Eylülde Ankara'ya gidecekleri muhtemeldir" cümleleri ile okuyucusuna duyurmuştur (Ünal, 4 Eylül 1935, Y1l: 1, Sayı 204).

Mihri İffet Pektaş Ankara'da Mecliste V. Dönem boyunca I. Yasama yılında 7 Mart 1935 (TBMM ZC V/I, 1935:26), II. Yasama yılında 6 Kasım 1935 (TBMM ZC V/6, 1935:9), III. Yasama yılında 9 Kasım 1936 (TBMM ZC V/13, 1936:12), IV. Yasama yılında 5 Kasım 1935(TBMM ZC V/20, 1937:15)ve V. Yasama yılında 7 Kasım 1935 tarihlerinde Kütüphane Encümeni olarak seçilmiştir (TBMM ZC V/27, 1938:13).Ancak Kütüphane Encümeni olarak görev yaptı̆̆1 süre içerisinde Kütüphane Encümeni ilgili bir kanun teklifi olmadığı için hiçbir faaliyette bulunmamıştır. Aynı zamanda Mihri İffet Pektaş Başbakan İsmet İnönü ile birlikte Teşkilatı Esasiye Kanunu'nun 2,44,47,49,50,61,74 ve 75. Maddelerinin değiştirilmesine dair kanun teklifinde bulunanlar arasındadır (Sarısaman, 2019: 707$708)^{15} .1935$ yılında da o dönemde Malatya milletvekili olan arkadaşlarıla birlikte seçim bölgeleri olan Malatya için bir rapor hazırlamışlardır. Bu raporla Malatya'da su probleminin çözülmesi, bir çimento fabrikası ile bir pamuk ıslah istasyonunun açılmasını talep etmişlerdir. Ayrıca raporda Malatya için var olan Numune Hastanesinin faaliyete geçmesi ve şehrin her yerinde eğitime büyük katkısı olacak olan yeni okulların açılmasının gereğinden bahsedilmiştir ( Sarısaman, 2019:708).

Öyle ki TBMM Zabit Cerideleri incelendiğinde, genel olarak 1935 ve 1950 yılları arasında yapılan konuşmaların pek çoğu, eğitim, sağlık, aile, kültür, kadın hakları, ekonomi ve gençlik sorunları ile ilgilidir. (Yıldız, 2012: 118) Bu yıllarda kadınların hastalık, annelik gibi önemli anlarında alacakları yardımlar, sigorta hakları ve doğum

15 Ayrıntılı bilgi için bakınız Sarısaman, S., "Malatya'nın İlk Bayan Milletvekili Mihri İffet ve TBMM'deki Faaliyetleri” adlı makale. 
yapmaları durumunda haklarının ne olduğu ile ilgili görüşmeler yapılırken; bu mevzularla ilgili çalışan komisyonlarda en hassasiyetle çalışan yine kadın milletvekilleri olmuştur (Yıldız, 2012:124).Mihri İffet Pektaş katıldığı V. Dönem Meclis oylamalarında 374 oylamaya evet oyu kullanmıştır (Sarısaman, 2019; 709). Bu kapsamda Mihri Pektaş'ın TBMM V. Dönem Genel Kurulu'nda Beden Terbiyesi Kanunu dolayısıyla yaptığı konuşması şöyledir:

"Muhterem arkadaşlar, benden evvel kürsüye gelen muhterem Dâhiliye vekili ve doktor arkadaşlarım sporun bir millet için ne kadar önemli, ne kadar esasl bir mesele olduğunu ve hükümetin bu meseleye el koymakla ne kadar basiretli ve lüzumlu bir iş görmüş olduğunu çok güzel anlattılar. Buna ilave edecek fazla bir sözüm yoktur. Fakat üstünde durmak istediğim ve bu teşkilât kurulurken muhterem Hükümetin nazarl dikkatini bilhassa celbetmek istediğim bir nokta vardır. Türk'ün sporcu olduğuna hiç şüphem yoktur. Sonra bunun ihmâl edildiğinde hepimiz müttefikiz. Son senelerde spor faaliyetleri, çoktan beri tıkanmış bir oluğun açılması gibi, su, gelişi güzel akmış, başıboş, intizamsız cereyan etmiştir. Bir aralı, zannediyorum gençlerimize, spor namına bazı yanlış fikirler verilmiştir. Benim bilhassa üzerinde durmak istediğim cihet budur. Spor dendiği vakit her şeye rağmen kırarak dökerek birincilik kazanmak mevzuubahis olmamalıdır. Spor kelimesi, bir oyunda bütün kaidelere riayet ederek güzel oynamak, efendice oynamak ve neticede bazen efendi gibi kaybetmek, bazen efendi gibi kazanmaktır. Yoksa her ne olursa olsun kazanmak katiyen değildir. Spor, bilhassa gençler arasinda tesanüdü yaratmak, beraber çallşmak ve neticeyi beraber kazanmaktır; mesuliyeti beraber yüklenmek, sevinci ve zaferi beraber paylaşmak demektir. On dokuzuncu asrın sonlarında çok romantik ve biraz marazı derecede hassas, santimantal olan Avrupa 'ya sporu Ingilizler sokmuş, tekrar canlandırmışlardır. Şimdi olimpiyatları düşünecek olursak görürüz ki, Ingilizler hiç kazanamazlar ve bundan ne müteessir olurlar; ne de utanırlar, bana öyle geliyor ki kendi noktai nazarlarinca sporun asıl manasın anlatmış olmak için bunu, biraz da bililtizam yaparlar. Türkler haddizatında sporcudurlar. Bütün mânâsi ile sportmendirler, oyunların en çetini ve en amansızı harp oyununu çok güzel oynarlar, Türk 'ün bütün düşmanları da kabul ve tasdik etmişlerdir ki, Türk, harp oyununu efendi gibi oynar, efendi gibi kaybeder ve efendi gibi kazanir. Binaenaleyh Hükümetimiz bu yeni teşkilâtı kurarken, kendilerinden bilhassa rica ediyorum, sportmenliğin ne olduğunu çocuklarımıza tekrar ögretsinler. Güzel, dürüst ve efendi gibi oyun oynamanın esasını çocuklarımıza lütfen ögretsinler. Benim ricam bundan ibarettir. " (TBMM ZC,V/26, 1938:487, Güneş, 2009: 525)

\section{2.b. Mihri İffet Pektaş’ın VI. Dönem Meclis Çalıșmaları}

26 Mart 1939 tarihinde yapılan genel seçimler sonucunda milletvekili seçilen Emrullah Barkan, General Osman Koptagel, Mahmud Nedim Zapçı, Osman Taner, Mihri Pektaş, Abdulmutalip Öker, Dr. Hilmi Oytac, Vasıf Çınay, Muharrir Nasuhi 
Baydar, Mehmet Şevket Özpazarbaşı'na ait seçim mazbataları 27 Mart 1939 tarihinde Dâhiliye Vekâletince Başbakanlık Vekâletine gönderilmiştir (BCA 030.10.76.499.8; TBMM Arşivi Devre: VI, Kutu: 41; No: 281). Mihri Pektaş 939 oyla tekrar VI. Dönem Malatya milletvekili olarak seçilmiş, 3 Nisan 1939'da Meclis çalışmalarına başlamıştır (TBMM Arşivi Devre: VI, Kutu: 41; No: 281) ${ }^{16}$. Malatya yerel basınında Firat Gazetesi ${ }^{17}$ nde bu haber şöyle yer bulmuştur:

26-3-939 Pazar günü saat 9'dan itibaren Malatya vilayetinde mebus intihabına başlanarak saat 11.5 da bütün kazalarda intihap neticelenmiştir. 1008 Müntehib-i Sâniden 939 u seçime iştirak etmişler reylerini müttefikan C.H.P. Namzetlerine vermişlerdir. Bu suretle: Emrullah Barkan, General Osman Koptagel, Mahmud Nedim Zapçı, Osman Taner, Mihri Pektaş, Abdulmutalip Öker, Dr. Hilmi Oytac, Vasıf Çınay, Muharrir Nasuhi Baydar, Ticaret odası reisi Mehmet Şevket Özpazarbaşı, Vilayetimiz mebusluğuna seçilmişlerdir. Sayın mebuslarımızı candan tebrik eder muvaffaklyetler dileriz (Firat, 28 Mart 1939, Sal1, say1:533).

Malatya Milletvekili Mihri Pektaş bu dönem içinde Fevkalâde ve Birinci İçtimâ senelerinde Kütüphane, diğer senelerde Dîvânı Muhasebat Encümenine aza (üye) olarak seçildi. Mihri İffet Pektaş VI. Dönem Milletvekilliğinde 10 Nisan 1939 tarihinde 370 oy ile I. Yasama yılı (TBMM ZC, VI/1, 1939: 19; Günay, 2007: 521 ), 6 Kasım 1939'da 290 oy ile II. Yasama yılında Kütüphane Encümeni üyesi olmuştur (TBMM ZC, VI/1, 1939: 12). Yine bu dönemde 8 Kasım 1940, 7 Kasım 1941, 9 Kasım 1940 tarihlerinde üç yasama yılı için Sayıştay (Divanı Muhasebat) Encümenine üye olarak seçilmiştir (TBMM ZC, VI/ 14, 1940: 14; TBMM ZC, VI/ 21, 1941: 15; TBMM ZC, VI/ 28, 1942: 10). Ayrica, İnhisarlar Umum Müdürlügünün 1939 yılı bütçesi üzerine yapılan görüşmelerde de görüşlerini açıkladığı görülmektedir (Gökçimen vd, 2009: 327 )Konuşması ise şöyledir;

Arkadaşlar; ben söz istedikten sonra Ziya Gevher arkadaşımız kürsüye çıkarak aşağı yukarı söylemek istediğim şeyleri söylediler. Fakat bunları bir kere daha tekrar etmeği bir memleket kadını olarak vazife bilirim. Evvelâ bu mesele geçen senelerde de böyle idi. Ne vakit bu mesele bu kürsüde mevzubahs edilse; içer misin, zevkini bilir misin, gibi lâflar ediliyor. Bilâkis bu çok ciddî bir mevzudur. Çünkü memleketin sihhat ve nüfusu ile alâkadardır. Her ne kadar dairesi varidat temin etmekle mükellef ise de memleketin sihhati hiç bir zaman göz önünden uzak tutulmamak lâzımdır. Çünkü vazifesidir. Biz milletvekili olarak kendisinden bunu istiyoruz, istemek hakkımızdır. Sonra kürsüye çıkan doktor arkadaşlarımızdan bazıları bizi biraz hayrete düşürdüler. Biz onlardan daha kuvvetli bir müdafaa isterdik. Vaka votka şudur, viski budur ama bunların hiç birisi rakı ile kabili kıyas değildir. Bu her halde daha sert bir içkidir ve slhhat üzerinde yapacă̆ tesir de diğerlerinin yapacağının ayni değildir. Arkadaşlarımızdan biri de: gençlerin biraz içmesi lâzımdır, dedi. Bu iddiayı katiyen ve katiyen kabul etmiyorum. Gençler içki içmeğe hiç muhtaç değildirler. Gençlikleri neşelenmeleri

\footnotetext{
${ }^{16}$ Mihri Pektaş, Malatya merkezden 213 oy alırken kazaları olan Arapkir 74, Hekimhan 83, Akçadağ 87,Darende 67, Besni 105, Adıyaman 145, Kahta 75 ve Pötürge'den 90 oy almıștır.

${ }^{17}$ Fırat Gazetesi bu yıllarda Malatya'da Cuma ve Salı günleri çıkan siyasal yerel bir gazetedir.
} 
için kâfidir. Başka bir şeye ihtiyaç yoktur (Bravo sesleri, alkışlar). Evet, memleketi kuru yapmă̆a imkân yoktur. Bunu muhtelif memleketler tecrübe etmişler, iyi netice elde edememişler. Biz de tecrübe etmişiz, iyi bir netice elde edememişiz. İçki içmenin belki tamamen önüne geçilemez. Fakat pek âlâ müşkülleştirebilir. Bu hususta bilhassa vekilin nazarı dikkatini celbetmek istiyorum. Çok küçük şişeler içerisinde rakılar satılmaktadır. Ameleler, az gündelikli insanlar bunu kolaylıkla tedarik etmek imkânını bulabiliyorlar. Bunun önüne geçmek lâzımdır. Varşova'dan bahsettiler. Bu ne güzel bir kanun, cumartesi ve pazar günleri içki içmemek. Keşke bu kanun bizde de olsa, bunu samimî olarak arzu ederim. Bir insan içkiye düşünse, onu nasıl olsa tedarik eder, fakat düşün olmayanlar haydi içiverelim derler ve bu yüzden içtimaî bakımdan birçok zararlar hâsıl olur. Bunun önüne geçmek lâzımdır. Bilhassa sayın vekilin bu noktaya nazarı dikkatlerini celbetmek istiyorum. Küçük şişelerde satılan içkileri mümkün ise büyük şişelerde sattırsinlar ve sonra Sihhat vekilinden de kuvvetle isteriz ki burada sthhî ve hayatî ve memleket için nüfus meselesi olduğunu müdafaa etsinler (TBMM ZC, VI/2, 1939: 45; Resmi Gazete, 16 Temmuz 1938: 10300-10301).

Mihri İffet Pektaş VI. Dönemde Tokat milletvekili Galip Pekel'in verdiği Köy Kanunu'na ek kanunun teklifi ve Dâhiliye Encümeni mazbatası görüşülürken müzakerenin kifayetine dair sadece bir önerge vermiştir. Bu önergesi kabul edilmiştir ( TBMM ZC, VI/26, 1942: 164-165). Pektaş Meclis görüşmelerinde VI. Dönemde katıldığı 352 oylamaların tamamında da evet oyu vermiştir ( TBMM ZC, VI/1, 1939: 27).

\section{2.c. Mihri İffet Pektaş'ın VII. Dönem Meclis Çalışmaları}

14 Aralık 1942'de, hazırlanan ve 1943 seçimlerinden önce çıkarılan seçim yasasında sistem açısından fazla bir değişiklik olmamıştır. Yeni Seçim Yasasının ${ }^{18}$ çıkmasına rağmen 1943 seçimleri iki dereceli olarak yapılmıştır. 1943 seçimleri sonunda Meclise 455 milletvekili girmiştir. Bu sayının sadece 16'sı kadın milletvekilidir. Bu milletvekillerinin içinde TBMM'ye daha önceki dönemlerde seçilen kadın milletvekilleri de bulunmaktadır. Mihri İffet Pektaş'ta V ve VI. Dönem TBMM'de görev alan bu milletvekillerinden biri olarak meclise tekrar girmiştir ${ }^{19}$. Bu seçimlerin

\footnotetext{
${ }^{18} 1942$ Seçim Yasasına göre seçimlere katılabilmek için Türk olmak, Türkçe okuma yazma bilmek, yabancı uyruklu olmamak, kamu hizmetlerinden yasaklanmamış olmak, kısıtlı olmamak, herhangi bir suç nedeniyle ceza almamış olmak, birinci veya ikinci dereceden seçmen olabilmek için ise 22 yaşını, milletvekili olmak için de 30 yaşını doldurmuş olmak gibi yeni kararlar getirmiştir. 1931 ve 1935 seçimlerinde, ikinci seçmenlere nispeten tercih hakkı bırakan ve CHP üyesi olmayan adayların seçilmesine imkân tanıyan müstakil milletvekili uygulaması, 1939 seçimlerinden hemen sonra toplanan V. Kurultay'ın aldığı bir kararla değişmiş, yeni düzenlemeye göre, partili milletvekilleri arasından Büyük Kurultayın seçtiği ve CHP Meclis Grubu dışında faaliyet gösterecek olan "Müstakil Grup" uygulamasına geçilmiştir.

${ }^{19}$ Meclise yeniden giren kadın milletvekilleri; Sabiha Gökçül Erbay, Şehime Yunus, Emine Mebrure Gönenç, Benal Nevzat İştar Arıman, Fatma Şakir Memik, Nakiye Elgün, Fakiye Öymen, Belkıs Baykan, Sıddıka Mümine Şemsa İşcen, Muammer Develi ve Salise Abanozoğlu'dur. Bu dönem ilk defa
} 
diğerlerinden farkı Türkiye Cumhuriyetinde Cumhuriyet Halk Partisi'nin tek parti olarak katıldığı son seçimdir. Aynı zamanda 1943 seçimi tek partili dönemin de son bulduğu seçimdir. Bu tarihte sonra Türkiye Cumhuriyeti'nde çok partili hayata geçilmiş, Türk kadınlarını başka partide de görmek mümkün olmuştur(Güneş, 2009: 525; Yıldız, 2012: 102 ). Mihri Pektaş'ın bu son dönem milletvekilliğinde de öncekilerde olduğu gibi Malatya'dan seçilmiştir. Malatya'da o yıllarda Malatya'da Cuma ve Salı günleri çıkan siyasal yerel bir gazete olan Firat Gazetesi bu haberi okuyucularına o yıllarda şöyle duyurmuştur:

28-2-943 Pazar günü saat 9 da Belediye salonunda ikinci seçmenlerin iştiraki ile vilayetimiz mebuslarının seçimi yapılmıştır. Seçim tam saat 9 da bandonun çaldiğ istiklal marşından sonra ve Belediye reisi Şefik Tugay'ın seçimin sureti tarzı hakkında kısa bir hitabesini müteakiben başlamıştır. Illk önce Sayın Valimiz Fahri özen ve parti müfettişimiz Midhat Aydin reylerini istimal etmişlerdir. Bundan sonra sirastyla merkez mahallatı (mahalleler) merkeze bağlı nahiyelerin seçmenleri reylerini vermeye başlamışlardır. Seçim tam bir düzen içinde ve 2 buçuk saat gibi çok kısa bir zamanda bitmiştir. Saat 11.30 da sandık açılmış ve merkez kazaya ait 213 rey puslası (pusulası) görülmüştür. Reyler kısa bir müddet içinde tasnif edilmişs ve aşağıda isimleri yazılı zevatın mebus seçildikleri anlaşılmıştır. Emrullah Barkan, Nasuhi Baydar, Mutalip Öker, Cafer Özelçi, M. Şevket Özpazarbaşı, Mihri Pektaş, Halit Sağıroğlu, Osman Taner, Mahmud Nedim Zapçı, Tevfik Temelli, Kemal Sayın.

Fırat: Değerli mebuslarımızı tebrik eder, yurda ait türlü başarılar dileriz. Yine aynı gazetenin "Mebuslarımı Gitti” başlı̆̆ altında "8 Martta Meclisin içtimainda bulunmak üzere 7nci devre intihabında seçilen mebuslarımızdan vilayetimizde bulunanlar bugünkü trenle Ankara'ya hareket etmişlerdir. İstasyonda seçkin bir zevat tarafindan uğurlanmışlardır. Değerli mebuslarımıza hayırl yolculuklar temenni ederiz" (Frrat, 2 Mart 1943, Sal1, sayı: 934).

Mihri İffet Pektaş 971 ikinci seçmen oyu ile günümüzde "Dünya Kadınlar Günü" olarak kutlanan 8 Mart 1943 günü mecliste ant içerek üçüncü kez Malatya milletvekilliğine başlamıştır. 15 Mart 1943 tarihinde Gümrük ve İnhisarlar Encümeninde oy tasnifinde görev almıştır (TBMM Arşivi Devre: VII, Kutu: 42; No: 543; TBMM ZC VII/1, 1943: 16) ${ }^{20}$. Bu dönemde 2 güven oylamas 237 oylamaya katılmış tamamına evet oyu kullanmıştır. İç ve Dış politika ile ilgili kanun tekliflerinde de evet oyu kullanmıştır. İç politikada “ Atatürk'ün Anıtkabir İnşaatına dair kanun" , "Çiftçiyi Topraklandırma Kanunu", "Varlık Vergisi hakkında 4305 say1lı ek kanun" yine o dönemde dış politikada "Almanya ile siyasi ve iktisadi ilişkilerin kesilmesine dair takrir", "Amerika Birleşik Devletleri Hükümeti tarafindan Cumhuriyet Hükümetine verilen on milyon dolarlık kredi anlaşmasının

TBMM 'ee seçilen kadın milletvekilleri ise; Aksoley, Hasene Ilgaz, Emine Mebrure, Saada Emin Kaatçılar ve Tezer Taşkıran'dır.

${ }^{20}$ Malatya merkezinden 211 oy alırken, diğer kazaları olan Pötürge 106, Hekimhan 61, Akçadağ 87, Darende 61, Besni 119, Adıyaman 147, Kâhta 55 ve Arapkir'den 74 oy almıştır. 
onanması" gibi önemli kanun tekliflerinde olumlu oy kullanmıştır ( Sarısaman, 2019: 716).

\subsection{Mihri İffet Pektaş'ın Ailesi ve Meclis Dışı Çalışmaları}

Mihri Pektaş 1923 yılında eşi Hüseyin Bey'le birlikte Lozan Antlaşması için Lozan'a gitmiştir (Yıldız, 2012:102). Lozan'da yaşadığı duyguları Deniz Kaynak'a verdiği röportajında şu sözlerle ifade etmiştir;

"Lozan... Seyahat hatıralarımı mı soruyorsunuz? Bilmem ki hangisi sizi alakadar eder? Lozan... Hayatımdaki en büyük Privilej'lerden (ayrıcalık) biri de Lozan'ı yaratmak için nasıl çalışıldığını yakından görebilmek firsatına nail oluşumdur. $O$ ne derin sevinçti! Büyük başarının verdiği gurur, ilerisi için sonsuz ümitler ve önüne geçilmez bir atılmak hevesi... Düşünüyorum: Duyguların en tatlıs sonra geldi. Yani, bunların hiçbiri, meşruiyette hissettiklerimiz gibi cılk çıkmadl, adım adım büyüdü ve tatmin edildik... Londra'da ilk resmi seyahatim olduğu için çok heyecanlı idim. Ingilizleri, ev sahibi olarak çok nazik ve sevimli buldum. Ingiltere, feminizmin ebedi yurdudur. Onun için bana gösterilen alaka inanılmayacak kadar genişti.

Her taraftan gazete muhabirleri, fotoğrafçılar, davetler ve bir sürü konferans teklifleri... Vaktin darlığından bir kısmını atlatmak lazım geldi. Fakat bir çayda, bir feminist grubuna, birdenbire bir iki söz söyleyecektim. Hayatımda ilk defa böyle bir şeye maruz kallyordum. Neler dediğim pek hatırımda yok, fakat Hear! Hear! Sözleri sağdan soldan geldikçe, gösterilen alakaya şaştım. Bu dikkati ifade eden,

dikkate davet eden bir sözdür!"

(http://www.5harfliler.com/malatya-mebusu-bayan-mihri-pektas).

İyi derecede İngilizce ve Fransızca bilen Pektaş'ın bilim dünyasına yaptığı en büyük katk1, 1960 yılında Willıam Mitchell Ramsay'in "Anadolu'nun Tarihi, Coğrafyası" adlı kitabını Türkçeye çevirmesi olmuştur. Kitabın konusu ile ilgili olarak Coğrafya ilminin önemini " Bir millet için geldiği yeri bilmek gideceği istikameti tayin etmek kadar mühimdir" sözleriyle ifade etmiştir. Ayrıca, Hilal-i Ahmer, Himaye-i Etfal ve Kadıköy Fıkaraperver Cemiyeti gibi yardım kuruluşlarında görev alan Pektaş Kadıköy Fukaraperver Cemiyeti'nde, Himaye-i Eftal ve Hilal-1 Ahmer'in hastabakıcılık kolunda da mağdur insanlar için önemli hayır çalışmalarında da bulunmuştur. (Gökçimen, 2009:327; Güneş, 2009: 525; Yıldız, 2012:10;) ${ }^{21}$.Mihri İffet Pektaş 24 Ağustos 1936 tarihinde III. Türk Dil Kurultayı'nda Güneş-Dil Teorisi ve Dil Karşılaştırmaları Komisyonuna seçilmiştir (Sarısaman, 2019: 703).

${ }^{21}$ Sadık Sarısaman makalesinde bu kitabı Mihri Pektaş'ın 1935'ten önce çevirdiğini yazmıştır. Bu bilgiyi Kurum gazetesindeki bir habere ve Pektaş'ın 1935 yılında TBMM'ye verdiği özgeçmişine dayandırmaktadır. 
Mihri İffet Pektaş 1935 yılında İstanbul Üniversitesi konferans salonunda XII. Uluslararası Kadın Kongresi'nde dünya barışı ile ilgili toplantıda yaptığı konuşmada I. Dünya Savaşı'ndan sonra barışın korunması gerektiğini işaret ederek, bütün milletlerin işbirliği yapmalarının gerektiğini belirtmiştir. Türkiye Cumhuriyeti’nin de bu amaçla Balkan Paktı'nı kurduğunu ifade etmiştir (Sarısaman, 2019: 703). Milletler Cemiyeti'nin Eylül 1936 tarihinde yapacağı toplantıya Türkiye Hükümet adına Malatya Milletvekili Mihri Pektaş gönderilmiştir ${ }^{22}$ (BCA 030.18.01.02.68.73.13). Yine 1945'te Birleşmiş Milletler Teşkilatının kurulmasıyla birlikte 1946'da da BM Ekonomik Sosyal Konseye bağlı olarak Kadının Statüsü Komisyonu kurulmuştur. Evrensel New York' ta toplanacak olan Birleşmiş Milletler İktisadi ve İçtimai Konseyi'nin(Çalık, 2015: 1125; ) ${ }^{23}$ Kadın Hakları" Komisyonuna Türkiye Cumhuriyeti'nin temsilen Mihri Pektaş'ın gitmesine karar vermiştir (BCA 030.18.02.112.89.7). 1947-1970 yılları arasında Birleşmiş Milletler Kadın Hakları Komisyonu'nda Türk delegesi olarak görev yapmıştır (Sarısaman, 2019:704).

13 Mayıs 1949 Cuma günü Ankara'dan İzmir Milletvekili ve Türk Kadınlar Birliği'nin Genel Başkanı Latife (Bekir) Çeyrekbaşi, Ankara Milletvekili ve Genel Başkan Vekili Mebrure Aksoley, Seyhan Milletvekili ve Genel Sekreter Makbule Diblan, Başyazar İffet Halim Oruz'la beraber İstanbul'a Birliğin İstanbul merkezini kurmağa teşebbüs eden üyelerle görüşmek üzere gelmişlerdir. Bu kapsamda Pazar günü Eminönü Halkevinde yapılan toplantıya müteşebbis(girişimci) heyet üyeleri Halim Oruz, Dr.PakizeTarzi, Av. Süreyya Ağaoğlu, Cavidan Yamut, Emel Gürler, Seniha Rauf, Aliye EsatEfsayiş Suat, Nasip Diblan, Safiye Hüseyin Elbi ile birlikte Mihri Pektaş’ta katılmıştır. (Kadın Gazetesi, 16 Mayıs 1949: 1-5; Dişbudak, 2008: $80)$.

$\mathrm{Bu}$ kapsamda sonraki yıllarda Birleşmiş Milletler Kadınlarının Hakları Komisyonu'nun 05 Ocak 1948 tarihinde New York'ta yapacağı ikinci toplantısına, 21 Mart 1949 tarihinde Beyrut'ta yapacağı üçüncü toplantısına, 08.Mayıs 1950 tarihinde New York'ta Lake Success'de yapacağı dördüncü toplantısına Türkiye'yi temsil etmek üzere Mihri Pektaş'ın gitmesine Bakanlar Kurulu tarafindan karar

\footnotetext{
${ }^{22} \mathrm{Bu}$ toplantıya Hariciye Vekili Dr. Tevfik Rüştü Aras (başkan olarak), Dâhiliye Vekili (CHP Genel Sekreteri) Şükrü Kaya, Cumhurbaşkanlığı Genel Sekreteri Hasan Rıza Soyak, Sivas Milletvekili Necmeddin Sadıkın (delege), 4. Daire Şefi Bedi Arbel, Hariciye Hususi Kalem Müdürü Refik Âmir Kocamazın (Müşavir), Dâhiliye Hususi Kalem Müdürü Arif Mardin ve Büyük Millet Meclisi Bütçe Encümeni Kâtibi Nuri (kâtip olarak) bey de katılmıştır. Heyete iki emniyet memuru tahsis edilmiş ve kendilerine gidip gelme yol masraflarından başka Türkiye sınırlarından başlamak üzere 02.06.1936 tarih ve 2/4798 sayılı kararnameye göre gündelik verilmesi karara bağlanmıştır Heyetin Başkanın gündeliği 124.21 Fransız Frangı arttırılmıştır. Heyetin, bazı devlet merkezlerine de uğraması, Cenevre ve sair uğradığı yerlerde heyet başkanı için istirahat kabul salonu, heyet için ise çalışma odaları bulunan bir daire tutulması, otomobil kiralanması daktilo muhabere ücreti ve ziyafet gibi yapılacak masrafları için de döviz müsaadesi verilmiştir. Ayrıca heyetle gideceklere siyasal pasaport verilmesine Hariciye Vekilliği'nin 27.08.1936 tarih 161444/35 sayılı tezkeresi ile onay verilmiştir.

${ }^{23} 21$ Haziran 1946 tarihinde kurulan Kadının Statüsü Komisyonu. Ekonomik ve Sosyal Konsey’in en işlevsel komisyonlarından birisidir. Komisyonu'nun en temel amacı, kadın ve erkeklerin eşitliği ilkesinin uygulanmasını sağlamaktır. Komisyon, kadınların ekonomik, sosyal, siyasal, medeni, toplumsal eğitimsel konularda geliştirilmesi ve desteklenmesi için Ekonomik ve Sosyal Konseye öneriler ve raporlar hazırlayarak, kadın hakları konusunda acil çözüme ihtiyaç duyulan konularda önerilerde bulunarak uygulanabilmesi için stratejiler geliştirmek amacındadır.
} 
verilmiştir (BCA 030.18.01.1115.77.13;BCA. 030.18.01.02.118.101; BCA. 030.18.01.02.122.37.6).

Mecliste sayı bakımından azınlık olarak yer almalarına rağmen Mihri Pektaş ve diğer kadın milletvekillerinin, meclisteki oturumlara çoğunlukla katıldıkları görülmüşsür. Ayrıca bu milletvekillerinin ülke sorunlarının yanında, kadın sorunlarına karşı duyarlılıkları, bu konuda yapılan etkinliklere iştirakleri ve hatta mecliste yaptıkları konuşmalarıyla "Kadın" konusuna çok önem vermişlerdir. Öyle ki TBMM Zabıt Cerideleri incelendiğinde, genel olarak 1935 ve 1950 yılları arasında yapılan konuşmaların pek çoğu, eğitim, sağlık, aile, kültür, kadın hakları, ekonomi ve gençlik sorunları ile ilgilidir. Bu yıllarda Mihri Pektaş ve kadın milletvekilleri kurulan bu komisyonlarda Türk kadınlarına hastalık, sağlık, annelik ve sigorta haklarının verilmesi gibi konularda yapılan çalışmalara ön saflarda katılmışlardır.

Milletvekilliği bittikten sonra da esas mesleği olan öğretmenliğe devam eden Mihri Pektaş, İngilizce ve Fransızca öğretmeni olarak 1946'dan 1961 yılına kadar önceden çalıştığı Robert Koleji'nde görev yapmıştır. 1958 ile 1961 arasında ise bu okulun mütevelli heyeti içinde de yer almıştır. Türk siyasi tarihinin ve Robert Kolejinin önemli simalarından, açı mavi gözlü, beyaz tenli ve orta boylu olan Mihri İffet Pektaş Hanımefendi 4 Temmuz 1979 'da hayata gözlerini yummuş, İstanbul'da Aşiyan Mezarlığı'nda toprağa verilmiştir. Mihri Pektaş, pek çok hayır kurumunda görev almış bir Türk kadını olarak her açıdan yeni Türkiye'nin çağdaş modern öncü kadın figürlerinden biri olmayı başarmıştır. (Güneş, 2009: 525; Yıldız, 2012:102 ).

\section{Sonuç}

Eski Türk toplumlarında kadınların, toplum içerisinde sahip oldukları statü ve değer diğer milletlerin kadınlarıyla karşılaştırıldığında, Türk kadınının çok daha önemli bir konumda bulunduğunu söylemek mümkündür. Ancak Türk kadını; Türk devletlerinin tarihsel süreci içerisinde karşıllaştı̆̆ 1 hem dinsel etkenlerden hem de Bizans ve Arap topluluklarının kültürlerinden etkilenerek eski değerini unutup kendi kültürüne uzak bir yaşam tarzında hayatına devam etmiş̧tir. Kadınların bu durumu Osmanlı klasik döneminde kendini çok daha belirgin bir şekilde göstermiştir. Ancak Batılılaşma hareketinin yoğun olarak uygulandığı Tanzimat (1839-1876) ve Meşrutiyet (1908-1918) dönemleri kadınlarla ilgili sorunlar için bir kırılma noktası olmuş ve kadınlara bazı haklar verilmiştir. Fakat I. Dünya Savaşı ve Kurtuluş Savaşı yıllarında hem cephede hem de cephe gerisinde erkeklerle omuz omuza mücadele veren kadınlar, bu mücadelelerini sosyal ve siyasal haklarını almak için de vermişlerdir. Cumhuriyete kadar siyasal alanda çok fazla talepleri olmayan Türk kadınlarının, cumhuriyet sonrası talepleri yoğunlaşmıştır. 29 Ekim 1923 'te Cumhuriyet'in ilanı Türk İnkılabının bir parçası olarak kadınların hak ve statü kazanmalarının önünü açmıştır. Kadın-erkek eşitliğini her daim savunan Atatürk, bu konudaki çalışmalarını diğer inkılaplarında olduğu gibi bir sistem içerisinde zamana yayarak yapmıştır. Bu destekle Cumhuriyet dönemi kadınları ilk adımda Kadınlar Halk Fırkası ve Türk Kadınlar Birliği Cemiyeti’ni kurmuş, ikinci adımda ise 3 Nisan 1930 Belediye, 26 Ekim 1933 Muhtar ve İhtiyar Meclisi ve 5 Aralık 1934 
Milletvekili seçimlerinde Seçme ve Seçilme Hakkını kazanmışlardır. Bu kapsamda Türkiye Cumhuriyeti'nde bir dönüm noktası olan 8 Şubat 1935 günü yapılan TBMM V. Dönem genel seçimlerinde TBMM'ye 18 kadın milletvekili girmeyi başarmıştır. 1935 ve daha sonraki yıllarda yapılan seçimler tüm yurtta olduğu gibi Malatya yerel basınında da yakından izlenmiştir. Dönemin Malatya yerel gazetesi Fırat ve Ünal Gazetelerinde çıkan haberlerde seçimi kazanan Malatya milletvekillerinin seçim sonrası aldıkları oylar, Mecliste mazbatalarını almaları, göreve başlamaları ve Malatya'yı ziyaretleri büyük bir ilgi ile takip edilmiştir. $\mathrm{Bu}$ yerel gazetelerde seçimlere giren ve kazanan haberi yapılan milletvekillerinden biri, Türkiye'nin modern dünyaya geçiş sürecinde öncü kadınlarından biri olarak büyük görevler üstlenmiş, İngilizce ve Fransızca öğretmeni Mihri İffet Pektaş’tır. V. VII. VII. dönemlerde Malatya milletvekilliği yapan Mihri İffet Pektaş Mecliste sayı bakımından azınlık olmalarına rağmen diğer kadın milletvekilleri ile meclisteki oturumlara çoğunlukla katılmış ülke ve kadın sorunlarına mecliste yaptıkları konuşmalarda fikir beyan etmişlerdir. Mihri İffet Pektaş katıldığı oturumlarda kanun tekliflerine ve önergelerin hepsine evet oyu kullanmıştır. Milletvekilliği boyunca Mecliste sadece iki konuşma yapmıştır. Ayrıca o günün koşullarında kadın milletvekilleri hem ulusal hem de uluslararası yapılan etkinliklere katılarak "Kadın" konusuna ne kadar önem verdiklerini göstermişlerdir. Malatya Milletvekili Mihri İffet Pektaş da Kızılay, Çocuk Esirgeme Kurumu ve Fukaraperver Cemiyeti gibi yardım kuruluşlarında gönüllü görev almış bu çalışmalara ön saflarda destek vermiş bir Türk kadın siyasetçidir.

\section{Kaynakça}

Arşiv

BCA 030.18.01.1115.77.13.

BCA. 030.18.01.02.118.101.

BCA. 030.18.01.02.122.37.6.

BCA 030.18.01.02.68.73.13.

BCA 030.18.02.112.89.7.

BCA 030.10.76.499.8.

\section{Resmi Yayınlar}

T. C. Resmi Gazete 16 Temmuz 1938.

TBMM Zabit Cerideleri, IV/25, 1934

TBMM Zabit Cerideleri, V/1, 1935.

TBMM Zabit Cerideleri, V/6, 1935.

TBMM Zabit Cerideleri, V/13, 1936. 
TBMM Zabit Cerideleri, V/20, 1937.

TBMM Zabit Cerideleri, V/27, 1938.

TBMM Zabit Cerideleri, V/26, 1938.

TBMM Zabit Cerideleri, VI/1, 1939.

TBMM Zabit Cerideleri, VI/2, 1939.

TBMM Zabit Cerideleri, VI/14, 1940.

TBMM Zabit Cerideleri, V/21, 1941.

TBMM Zabit Cerideleri, VI/28, 1942.

TBMM Zabit Cerideleri, VII/6, 1943.

TBMM Albümü, TBMM Matbaası, Ankara, 1939.

TBMM Albümü, TBMM Matbaası, Ankara, 1943.

TBMM Albümü, TBMM Matbaası, Ankara, 1946.

TBMM Albümü, TBMM Matbaası, Ankara, 1950.

TBMM Albümü, TBMM Matbaası, Ankara, 1994.

TBMM Arşivi Devre: V, Kutu: 38, No: 271.

TBMM Arşivi Devre: VI, Kutu: 41, No: 281.

TBMM Arşivi Devre: VII, Kutu: 42, No: 543.

\section{Süreli Yayınlar}

Cumhuriyet, 6 Aralık 1934.

Firat 05 Şubat 1935.

Frrat 11 Şubat 1935.

Firat 28 Mart 1939.

Firat 03 Mart 1943.

Ünal 5 Şubat 1935.

Ünal 19 Ağustos 1935.

Ünal 23 Ağustos 1935.

Ünal 26 Ağustos 1935.

Ünal 4 Eylül 1935.

Kadın Gazetesi, 16 Mayıs 1949 
Milliyet, 2 Mart 1935.

\section{Tezler}

Dişbudak, Müge, (2008), Türk Kadınlar Birliği, Dokuz Eylül Üniversitesi Atatürk İlkeleri ve İnkılap Tarihi Enstitüsü Yüksek Lisans Tezi, İzmir.

Duroğlu, Sibel, (2007), Türkiye'de Illk Kadın Milletvekilleri, Ankara Üniversitesi Sosyal Bilimler Enstitüsü Tarih Anabilim Dalı, Yüksek Lisans Tezi, Ankara.

İşat, Ceren, (2006), Türk Kadınlar Birliğinde Devlet ve Sinlf İlişkileri, Ankara Üniversitesi Sosyal Bilimler Kadın Çalışmaları Anabilim Dalı, Yüksek Lisans Tezi Ankara.

Oruç, Selin, Gizem, (2010), Türk Kadınlar Birliği (1924-1935), Hacettepe Üniversitesi Sosyal Bilimler Enstitüsü Tarih Anabilim Dalı, Yüksek Lisans Tezi, Ankara.

Sümer, Çakır, Gülizar, (1999), Türkiye'de Kadın Milletvekilleri: 1935-1991, İnönü Üniversitesi Kamu Yönetimi Anabilim Dalı Yüksek Lisans Tezi, Malatya.

Yıldız, Muhammet, (2012), Türkiye'de Kadın Haklarının Siyasi Gelişimi (19231950), Atatürk Üniversitesi Atatürk İlkeleri ve İnk1lap Tarihi Enstitüsü Yüksek Lisans Tezi, Erzurum.

\section{KİTAP ve MAKALELER}

Afetinan Afet, (1992), Atatürkçü Düşünce, Atatürk Araştırma Merkezi, Ankara.

Afetinan Afet, (2000), Medeni Bilgiler ve M. Kemal Atatürk'ün El Yazılarl, Atatürk Araştırma Merkezi, Ankara.

Atatürkçülük I. (Atatürk'ün Görüş ve Direktifleri), Milli Eğitim Basımevi, Ankara: 1998

Atatürkçülük III. (Atatürk'ün Görüşv ve Direktifleri), Milli Eğitim Basımevi, Ankara: 1998

Bulut, Sedef ve Güzel, Vurmay, Miray (2017) “Ortadoğulu Kadın Gözünden Atatürk Döneminde Kadın Hakları: “Mısır Örneği” DTCF Dergisi 57 (1), s. 1-49.

Caporal, Bernard, (1982), Kemalizm'de ve Kemalizm Sonrasında Türk Kadını, Türkiye İş Bankası, Kültür Yayınları, Ankara.

Çalık, Tacettin, (2015), "Birleşmiş Milletler Organlarının İnsan Hakları İle İlişkisi””, İnönü Üniversitesi Hukuk Fakültesi Dergisi Özel Sayı,2, s. 1091, 1134.

Çanak, Erdem, (2016), “Atatürk'ün Yurt Gezilerine Bir Örnek: 1930- 1931 Gezisi”, TheJournal of AcademicSocialScience, 4(23), s. 128-178. 
Çanak, Erdem (2016), “TBMM'deki İlk Kadın Milletvekillerinden Esma Nayman ve Meclisteki Faaliyetleri”, TheJournal of AcademicSocialScience, 4(7), s. 26-41.

Demir, Yunus ve Rahime, Fulya, Yüksel, (2017), "Kemalist İdeolojide Hakkının Verilmesi Bir Lütuf mu? Yoksa Kazanılmış Bir Hak mı?” EducationScience, 3(2), s. $226-248$.

Doğramacı, Emel, (1992) “Atatürk ve Kadın Hakları” Atatürkçü Düşünce, Atatürk Araştırma Merkezi Yayınları, Ankara.

Feyzioğlu, Turhan, (1992) “Atatürk ve Kadın Hakları” Atatürkçü Düşünce, Atatürk Araştırma Merkezi Yayınları, Ankara.

Gökçimen, Semra, (2008), "Ülkemizde Kadınların Siyasal Hayata Katılım Mücadelesi, Ülkemizde Kadınların Siyasal Hayata Katılım Mücadelesi”, Yasama Dergisi, (10), s. 5-59.

Göksel Burhan, (1992) “Atatürk ve Kadın Hakları” Atatürkçü Düşünce, Atatürk Araştırma Merkezi Yayınları, Ankara.

Günay, Ş, Şenal, (2007), Türk Parlamento Tarihi TBMM - VI. Dönem ( 3 Nisan 1939-15 Ocak 1943), II/ 26, Türkiye Büyük Millet Meclisi Vakıf Yayınları, Ankara

Güneş, İhsan, (2000), Türk Parlamento Tarihi TBMM - V. Dönem (1935-1939), II/ 26, Türkiye Büyük Millet Meclisi Vakıf Yayınları, Ankara.

Güneş, İhsan, TBMM Arşivi, Özgeçmiş “Mihri Pektaş"; Türk Parlamento Tarihi (TBMM V. Dönem 1935-1939)

Hamzaoğlu, Mehtap,(2017), “Tanzimat'tan Erken Cumhuriyet Dönemine Türk Toplumsal ve Siyasal Yaşamında Öne Çıkan Kadınlar",lectiosocialis, 2(1), s. 74-92.

İlkhan, Serap, (2018), "II. Meşrutiyet Döneminde Türk Kadını”, Bayterek Uluslararası Akademik Araştırmalar Dergisi, 1 (1), s. 56-76.

Kızılkaya, Nezir (2016), Malatya Basın Tarihi (1923-2003), Malatya Valiliği Malatya Kitaplığı Yayınları.

Özer Sevilay, (2013), "Kadınlara Seçme ve Seçilme Hakkı Verilmesinin Türk Kamuoyundaki Yankıları", Atatürk Araştırma Merkezi Dergisi, XXI (85), s. 131-167.

Sağ, Vahap, (2001), “Tarihsel Süreç İçerisinde Türk Kadını ve Atatürk”, C.Ü. İktisadi ve İdari Bilimler Dergisi, 2(1), s. 9-23.

Sarısaman, Sadık, (2019), 'Malatya'nın İlk Bayan Milletvekili Mihri İffet Pektaş ve TBMM'deki Faaliyetleri”, History Studies, 11(2), s. 701-726.

Şimşek, Abdulazim, (2017), "II. Meşrutiyet Döneminde Batılılaşma Etkisinde Yapılan Feminizm Tartışmaları”, Ankara Üniversitesi Türk İnkılâp Tarihi Enstitüsü Atatürk Yolu Dergisi, 61, s. 341-364. 
Gökçimen, Semra (2009), Türk Parlamento Tarihinde Kadın Parlamenterler, TBMM 1935-2009, Hazırlayanlar Kanunlar Ve Kararlar Müdür Yardımcısı Yasama Uzmanlar Havvana Yapıcı Engin Kaya Dinçer Gültemen Taner Geçmez, Ankara.

Uzun, İsmail, (2017), "Kadın Haklarının Kazanılmasında Bir Cumhuriyet Kadını: Afet İnan(1908-1985)" Ahi Evran Üniversitesi Sosyal Bilimler Enstitüsü Dergisi (AEÜSBED), 3(1) s. 73-85.

Yetkin, Çetin, (1983), Türkiye'de Tek Parti Yönetimi (1930-1945), Altın Kitaplar Yayınevi.

Y1lmaz, Ahmet, (2011), "1930-Belediye Seçimleri Sürecinde Kamuoyu'nda "Kadın”a Yönelik Söylemler" ÇTTAD, X(22) , s. 141-164.

\section{Elektronik Kaynaklar}

http://www.5harfliler.com/malatya-mebusu-bayan-mihri-pektas/ 21.11.2018.

https://twitter.com/fsahinturk84/status/950069902005690368/21.11.2018.

Ek:1

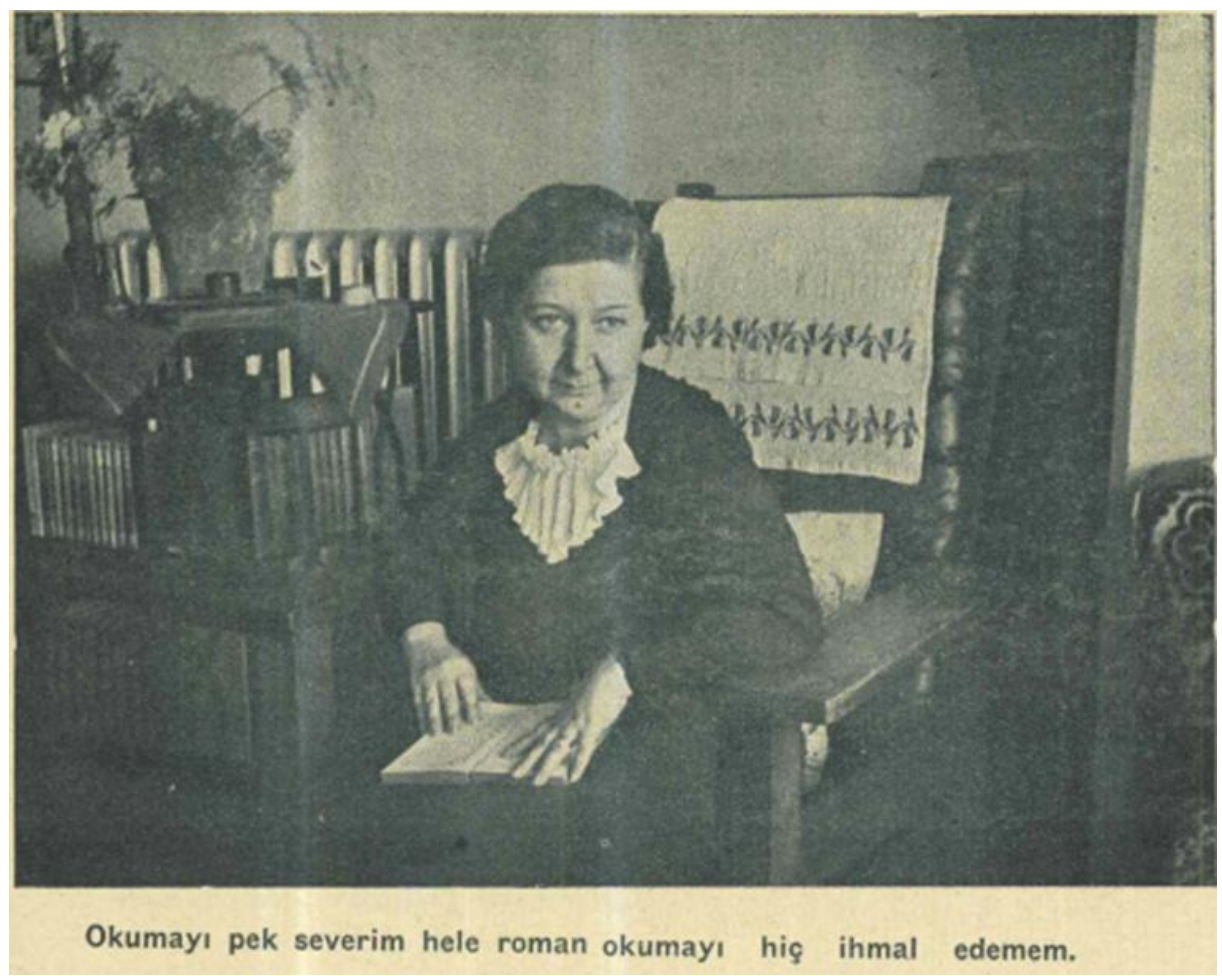

http://www.5harfliler.com/malatya-mebusu-bayan-mihri-pektas/ 21.11.2018. 
Ek:2

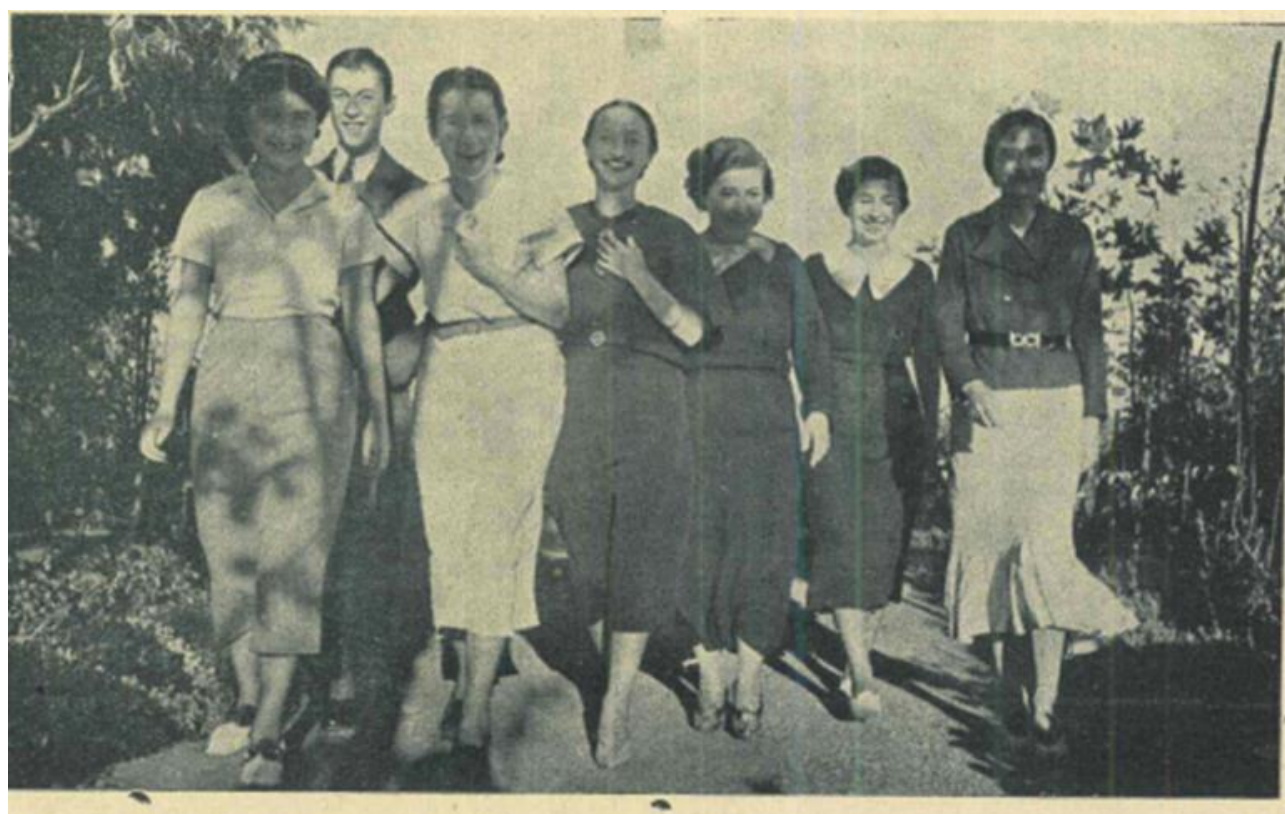

Hocalığı severek yaptım fakat ideal bir hoca olmadığımı tahmin ediyorum.

http://www.5harfliler.com/malatya-mebusu-bayan-mihri-pektas/ 21.11.2018.

Ek:3

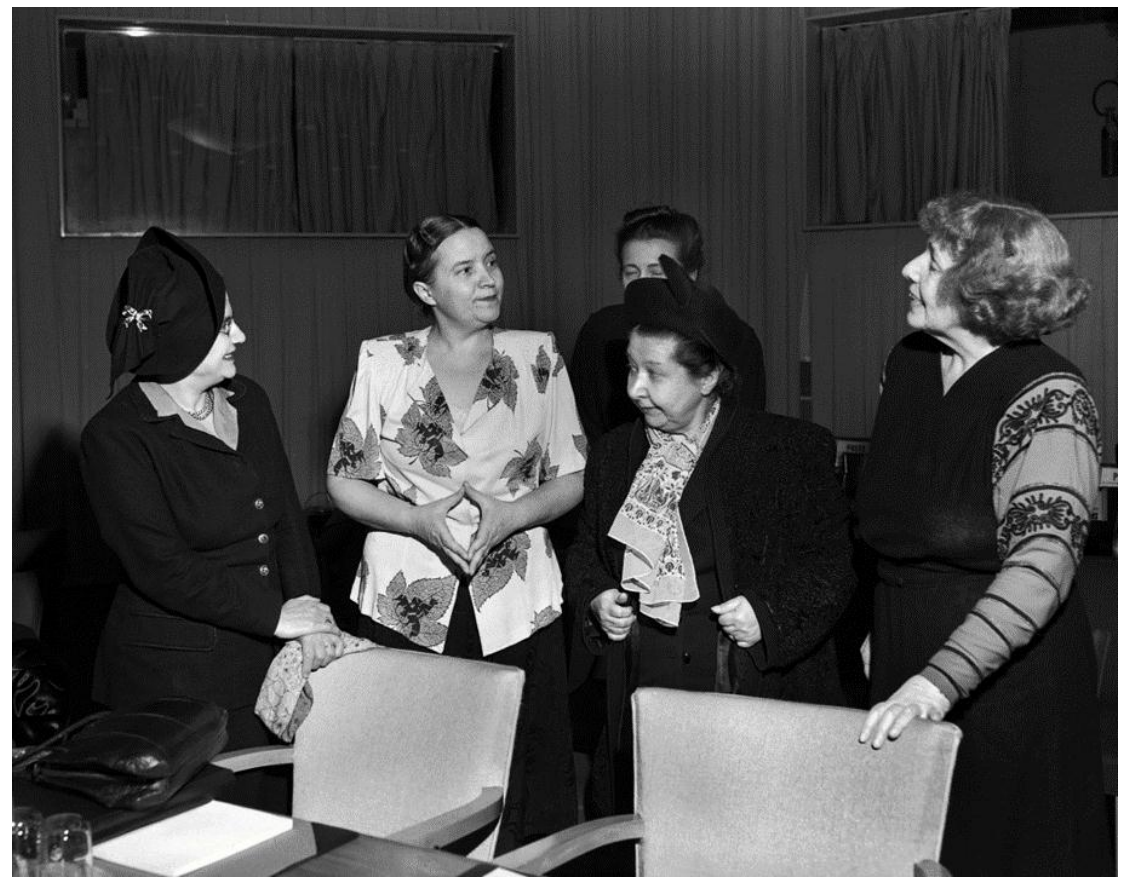

http://www.5harfliler.com/malatya-mebusu-bayan-mihri-pektas/ 21.11.2018. 
Ek:4

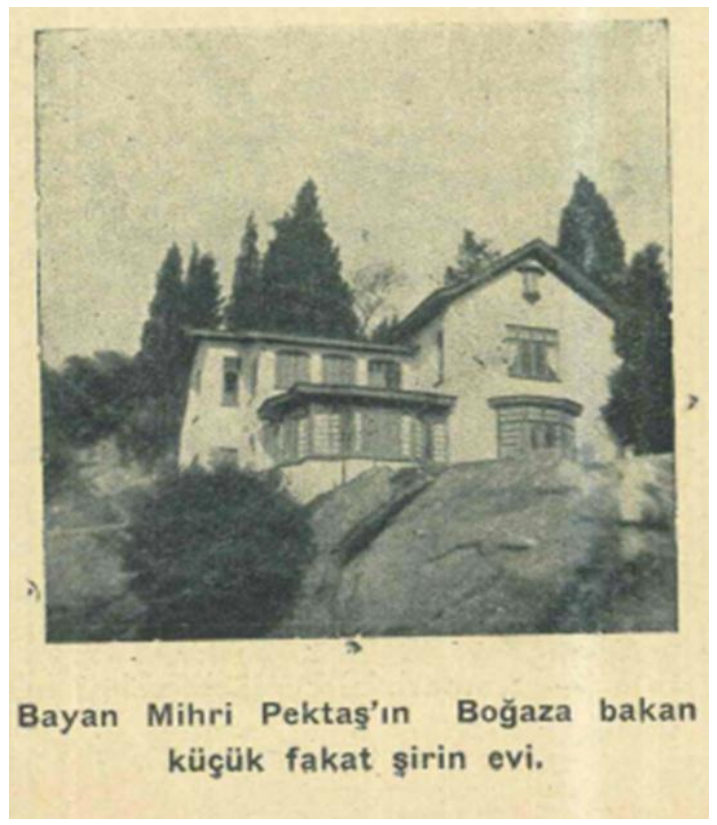

http://www.5harfliler.com/malatya-mebusu-bayan-mihri-pektas/ 21.11.2018.

Ek:5

\section{VEFAT}

Eski Bursa Vali muavinlerinden merhum Yusuf Bahattin Bey ile merhume Iclal Hanım'in kızlar,. Merhume Şcikưfe Kunter, merhume Halide Sözer ve merhumZiver Bey'in kardeşleri. Neclâ Soyak ve Saliveyda Soyak'in anneleri. Enver Soyak ve merhum Sungu Soyak'in kayınvalideleri, Gülgün. Necip, Edip. Hasan ve Ali'nin anneanneleri. Ali, Mona ve Janet'in bujyük kayınvalideleri. Soyak. Kunter. Tuzcu. Sbzer ve Canls ailelerinin büyúgü. Robert College eski müdürlerinden merhum Hüseyin Pektas' in kıymetli eși

\section{Eki Malatya mebusu ve Robert College emekli hocalarindan} MiHRi iFFET PEKTAS

\section{Katkı 45: Hüseyin Pektaş’in eşi Mihri İffet Pektaş'in vefat İlanı}


Ek:6

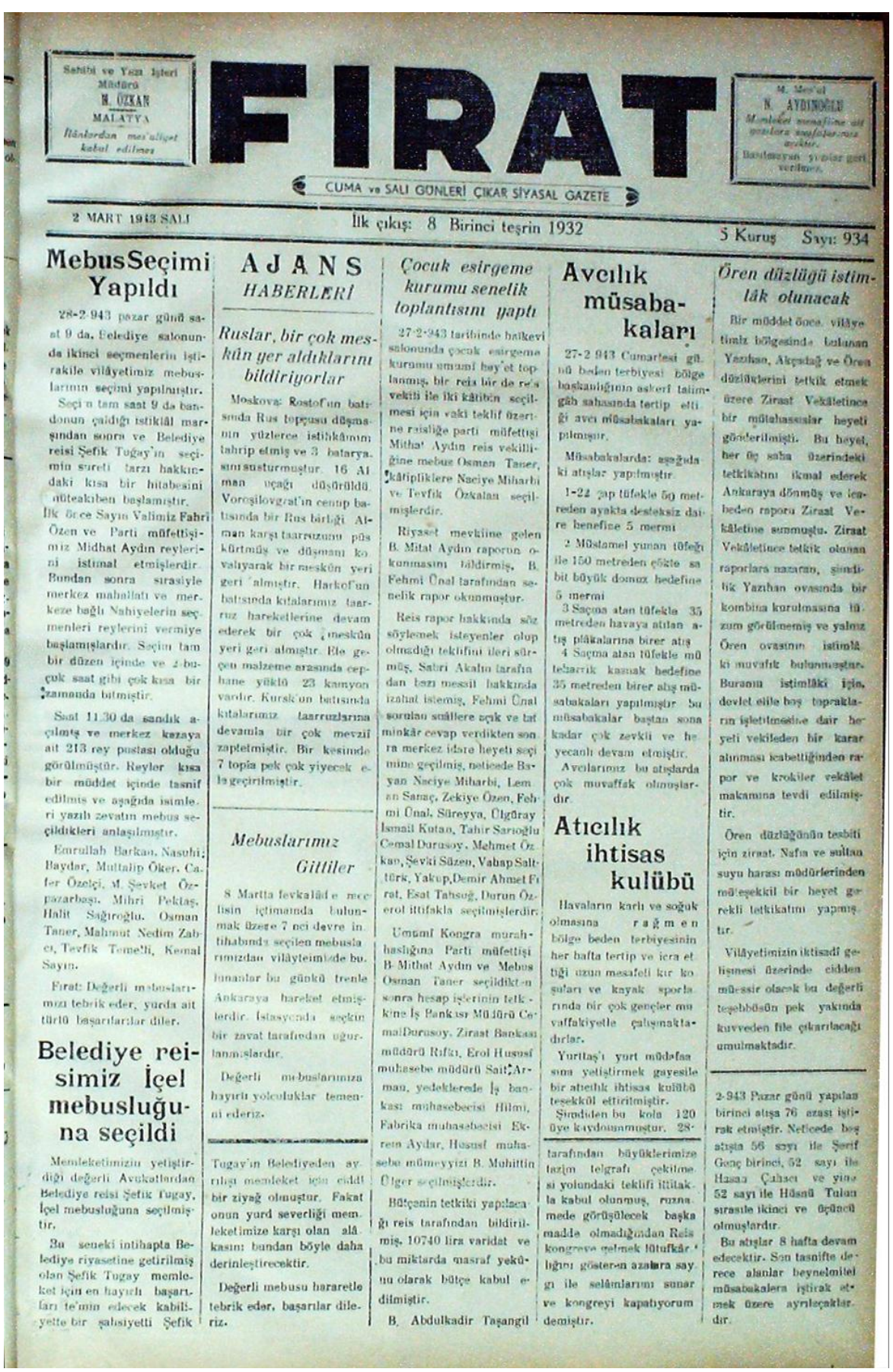


Ek:7

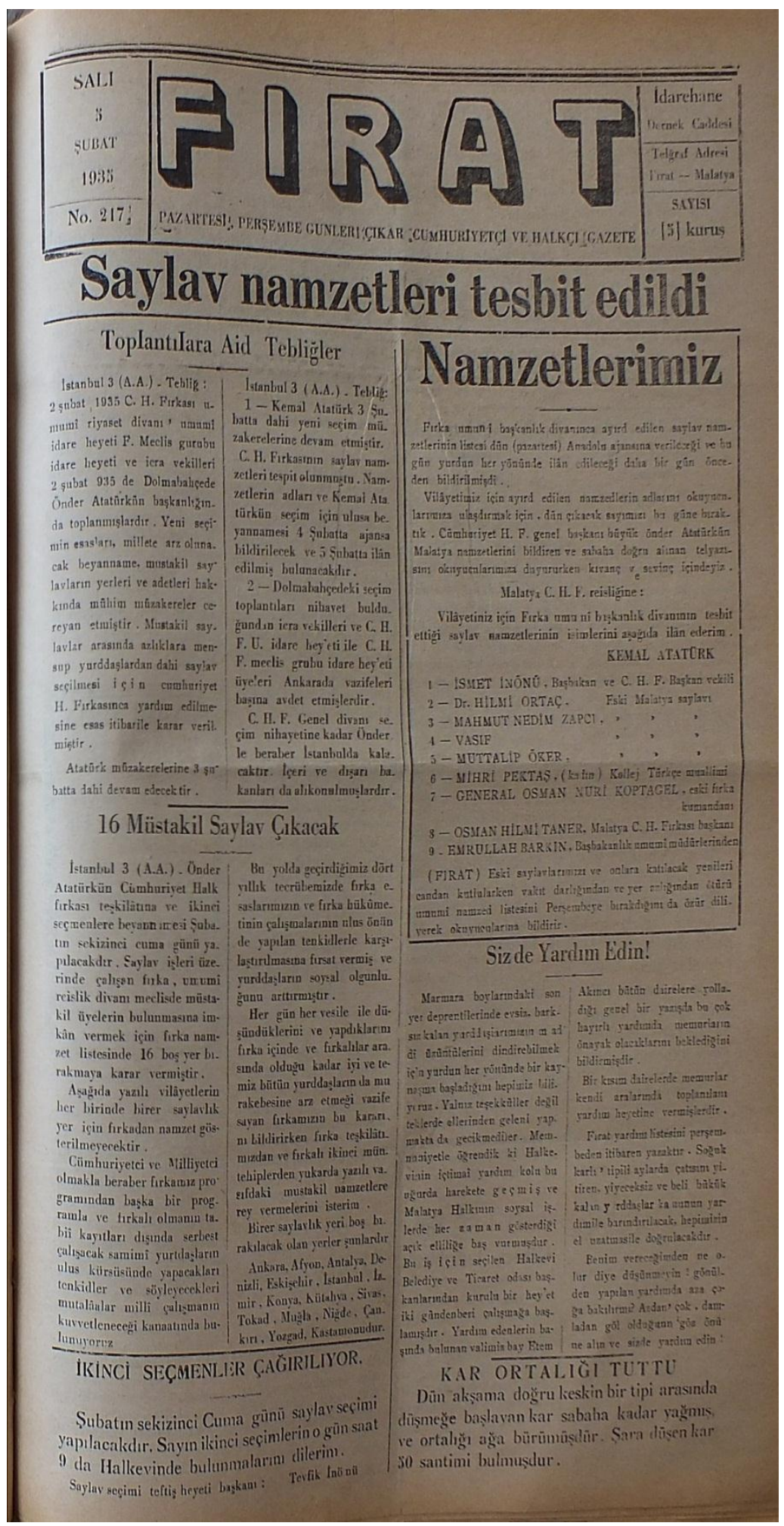


Ek:8

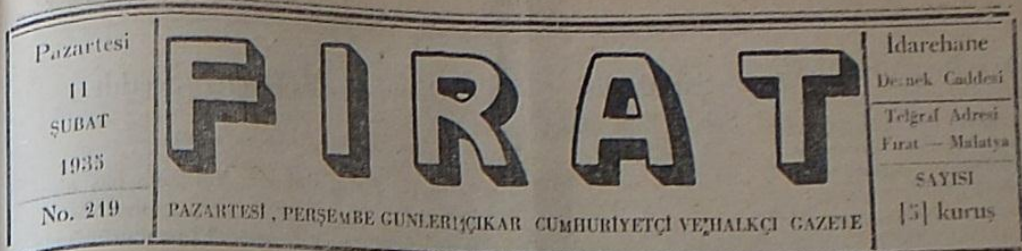

SAYLAV SECIMI ACUNA GÖSIERDI KI; TÜRK ULUSUNUN ATATÜRKE, PARTISINE INANC! VE GUVENCININ SONU YOKTUR .

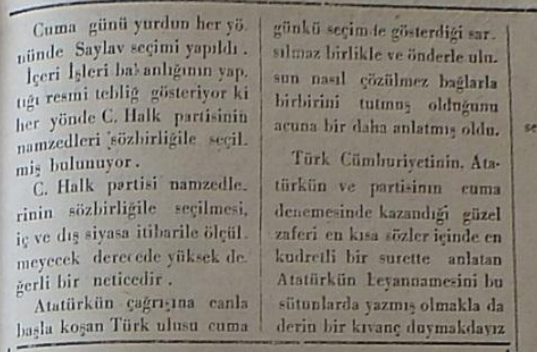

Atatükün Beyannamesi

Istanbul 8 (A A) - Reisic

Bana ve partime inanınız ve gäveninizi yine gissterdiniz.

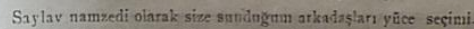

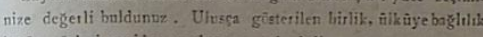

Hittin güzleri yeniden yưduninza cekmistir.

1935 seciminin bittigi bu 8 șnhat aksamt Thirkiye is ve diş

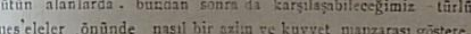
cgini bir daha acuna bildirmis olda.

Oz dilegimiz: Yurảun sùceligi, yarddasın genligiaidir.

K MÃL ATATOR

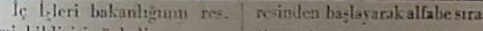

mi lildirisi sörledi.

Ankara 8 (A.A.) Cuma gïnii tile yemi zaylavlarınuz bildir

memlehetin her tarlinda ỳ- ötürü avnen yazamadik.

pllan saylar seçimi aymi günic

ótürü aynen yaramadik.

Bùtüu furba namzedleri sāz

399 saylavdan C. Bi. Firkas birligile her yönde secilmis

namzedleri ittifakla re oldugundan yeni saylavlan.

mżu adlerım oğrenmek is.

ryetle seçilmișlerdir. tẹen okuyuculanmızı ge

(Firat) Basda Atutirkiin cende vadigmz namzed lis

bulunduğn Ankara secim dai. tesine hakualarum dilerì.

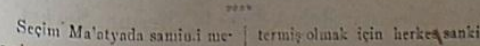

rasin: içinde yapuldt. Sant 8 yans vapyor.-Reyler niçio sal c

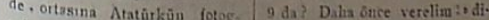

rafi konulmus, cevreni nît yerek

bayraklarrmula bezenmis tev. Suat 9 a seryek kala getis

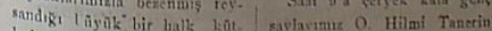

lesibin lieyecouls tezahthârleri a.

rakinda Halkevine getivillit.

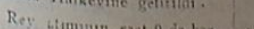

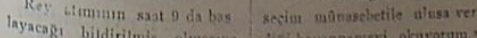

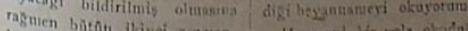

let sat \& d. Halkerini to. Heresanti bif sale obeca,

Itroung haluringatde

heyannamenin lice camlesi

Atatorke, puring

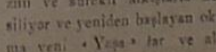

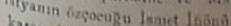

haty dugnhlen bayank sergi

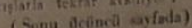

YENI SAYLAVLARIMIZ

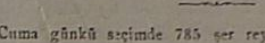

eilenler:

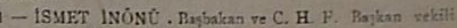

2 -Dr. HILNI ORTAC, Fski Malatya saylas

3 - MAHMUD NEDIM $Z$ A

4-VASIP

5 - MUTTALIP ÓKRR,
6- MIHRI PEKTAS. (kadin) Kollej Türice maltimi

7 - GENERAL OSMAN NUR! KOPDAGEL, , eskit furia

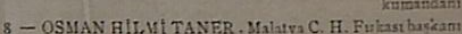

9. EMRULLAH BAREIN, Bashakanlik qumini mad durletinden

Genel Meclis Uyeleri Seçildi

Cuma gūnū yurdun her yōnūnde yapilan saylav seçimi Atatürke v 2 onun furkasina kar sı ulusun duveluğu sarsilmaz gûven ve inancı nasıl gōsterdivse bütūn vilâyetierde yaplan ge nel meclisi ùye seçiminden õtürü cumarteside Cümhurivet Halk Fırkasının ulusal hayat. taki yūksek varlığın bütün parlaklığıyle ka muya anlatan bir gün oldu.

Vilâvetler idaresi kanununun bazı madıle lerini değiştiren son kanunun muvakkat mad desinde genel meelis ũyesi seciminin ilk say: lay seçiminin yapılacă̆ı ay içinde bașarılıcă̆ı yazılıdır.

Içeri işleri bakanlığı, içinde buluaduğumuz avın hava șartlarımı gōz ônūne almıs ve kōy. lerde ki ikinci secmenlerin her seçim için aralik guinlerde merkezlere gidip gelmelerindeki zor luğu düsünerek' genel meclis üyesi seçiminin de saylav seçim gününūn ertesinde yapılna. sm būtūn vilâvetlere bildirmişıli. Bu itibarle cumartesi gūnū öteki vilàyetlerde olluğu gi. bi vilàyetimizin bũtun kazalarında da genel meclis ūye secimi vapilmıs ve cūmhurivet halk furkası namzedleri her yerde sõz birliğile se çilmislerdir.

Merkezde seçim șồle gecdi

Cumartesi siat sekiz... Halkevi salonları jkinci secmenler ve belediye ùyesi ile doluyor. Az sonra başda vali olmak ûzre vilávet ida re hey'eti ûyesi geldiler ... Bilindiği gibi genel meclis üve secim ida re hevitleri huzaran. (Sonu thinci esiola) 


\section{Ek:9}

SENE: I SIYISI HER YEILE [60] PARADIR SALI \$ SEBAT 1933 SAYI: 18

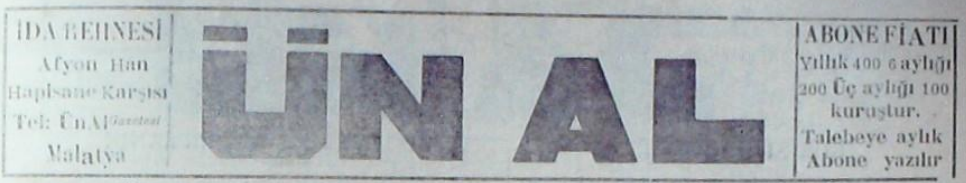

GÖNDELIK, CL MILUIYETCI, SIYASI, IIAYADIS VE IILLK GAZETESI

IIIRIIARII FELIKET ZEDELERINE YARDII

A : amana havzass mun-

ukismda vukua gelen

son zeizelelerde zarar gồrาn rutaslarımiza

Hilàlahuer ve dip̧er

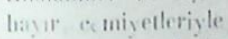

vuritun her tarafinda

vaplaa yarilimlar

ceimlon gime: atmak-

tawh"

Ba män:subele şetsrimizllede değerli val-

limiziil öncülük ali-

kasiylo lashy:an yar-

dıma diğer bütüง d:ı-

vair memuresni

mümkün olan yar-

Immlarun esirgemene-

ktodirler. Sonsuz bi:

istekle habaran te-

berrï yohimara daha

sona crmis olmad,

iẹin rehkam yazmiyo-

ruz toplanan yardma la

vilàyet Cumhurivet

halk firhas riyaseti-

ne vaurilmaktadhr.'Te-

berrüat bitince llalh

Furkası parayı liilali

ahmer cemiveti va-
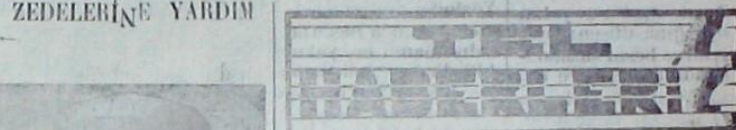

IAT. ITYANIN YENI SAYLAVL ARI

Firka Disanuea ye- Iac eshi Malatya sayni secimde Malatya lavi Vahmut Nedim Siılavlığına secilecek Zabitei eski Malatva namzedley hakkinda Saylavi Vası eski I ilayed Sayiase intih Malatya saylavi Mutencümeni biskan ta ib eski Malatya Bele!live reisi Ba Me- saylavi Mihri Pektas

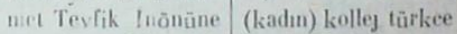
asağıdaki teblığ gel- muallimlerinden mistir. General Osman kabNalatya Belediyesine dagel eski Firka kuVilivetiniz ieiu firka mandam Tilayet niz iein firka mandam hilmi Tomer
umumi Baskanlık di- Osman hilm: vaunu teshit eưŭi Malatya Cumhuriyet Saylas namzedlerinin Halk firkası Baskanı Saylas namzedlerinin Eak firkas Baskam as:iğıda ilàn ederim. $\begin{aligned} & \text { Emrullah Barkıll bas- } \\ & \text { kanlik umum mü- }\end{aligned}$ General Ismet In- dürlerindendir önü Başbakan ve C. (ŨNAL) II. F. genel Baskan YENI SAYLAVLARI vekili Dr. Hilmi Or- CINDAN KUTI CLAB Bay Etom Ahmci

deki yurıdașlarımızia ulasdirilmasimu dileyecek ve yardima koșan Ialatyalıların yaslarını sunacaktır. Yeni Secim münasebetile Dün Yurdun Hertarafına Teblig Edilen Saylay Namzetleden sonra Ata Türkün millete yaptığı son beyanat gee vakıt kavuşduğundan yarın yazaeağız .

stasivle zelzole yerin

\section{Bu Als am Halke vinde Verilecek Konf ransa Gitmeyi Unutma}


Ek:10

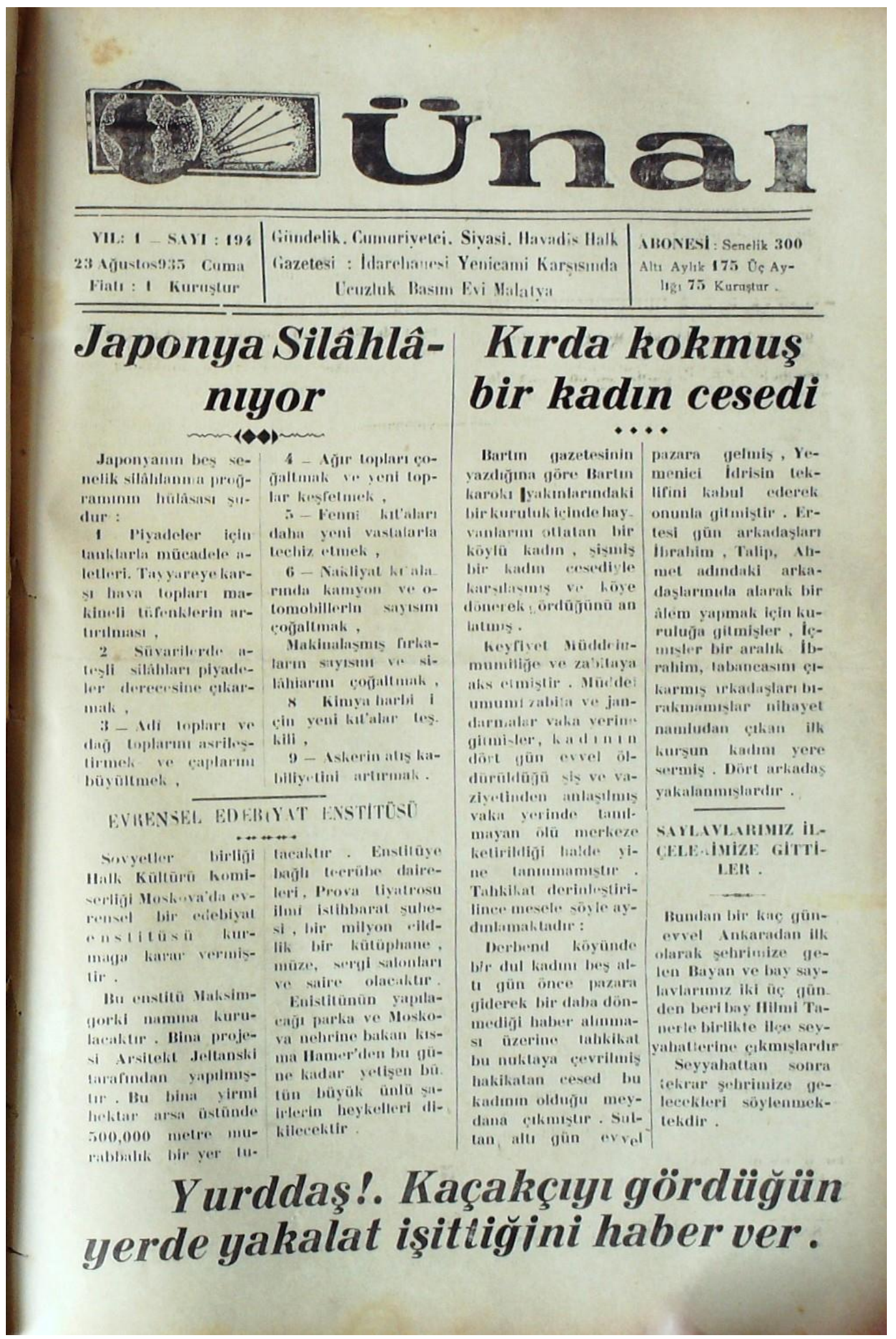


Ek:11

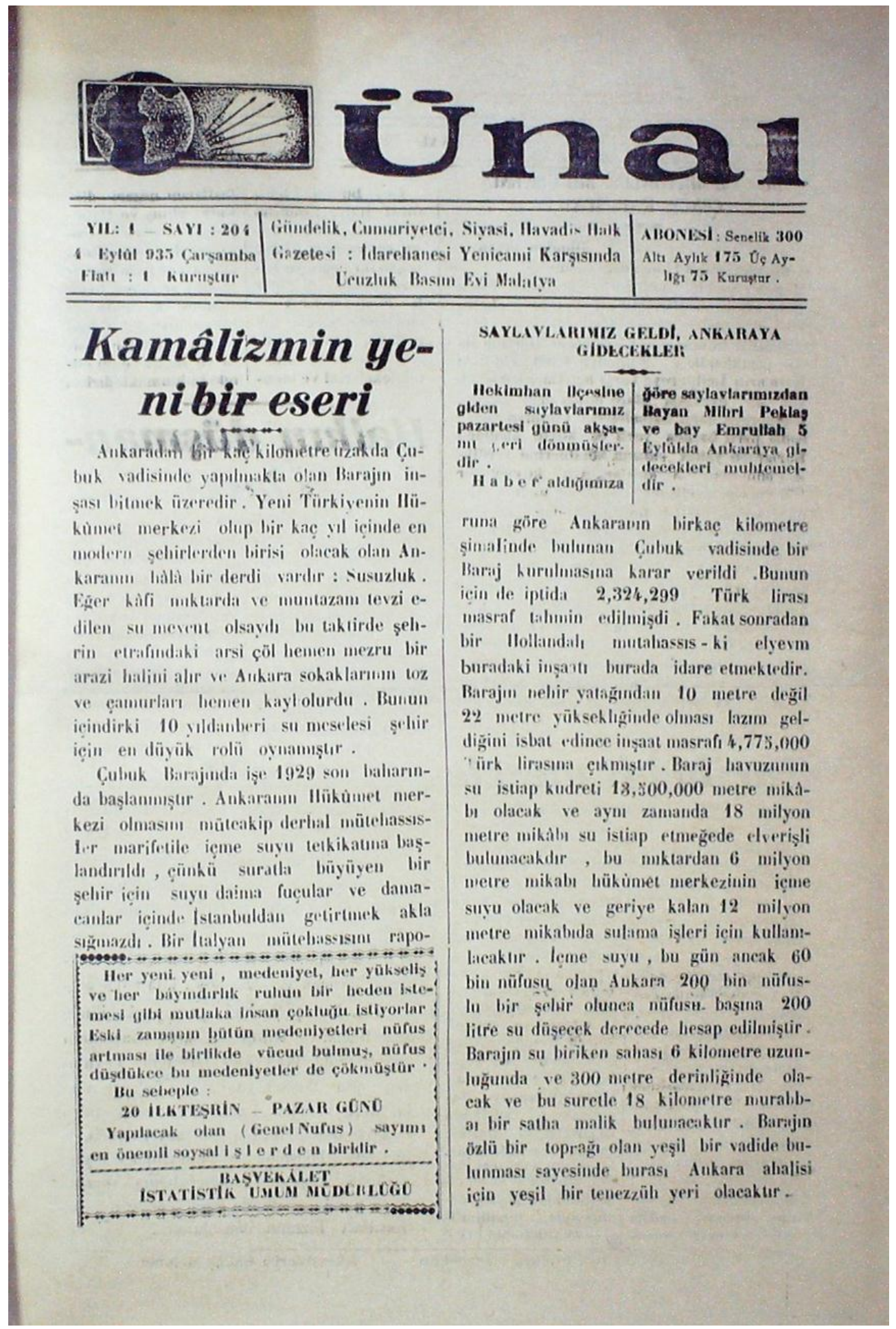

